\title{
Epidemiology of Botrytis cinerea on Grape: Wound Infection by Dry, Airborne Conidia
}

\author{
S. Coertze and G. Holz
}

Department of Plant Pathology, Stellenbosch University, Private Bag X1, 7602 Matieland (Stellenbosch), South Africa

Submitted for publication: March 2002

Accepted for publication: August 2002

Key words: Conidial behaviour, infection mode, latent infection, penetration

\begin{abstract}
This study describes the infection of fresh wounds on berries exposed to freshly deposited airborne Botrytis cinerea conidia, and on berries carrying previously deposited conidia and germlings (latent infections). Grapes at bunch closure and at the mature (harvest) stage, as well as mature, cold-stored grapes, were used. The grapes were dusted with dry conidia in a settling tower. The inocula were subjected to conditions commonly encountered by the pathogen in grape bunches: dry conidia on dry berries under dry conditions, dry conidia on dry berries under high relative humidity, and dry conidia exposed to a film of water on the berry surface. The mean number of wounds that yielded $B$. cinerea decay 14 days after inoculation was calculated. Fluorescence microscopy revealed that conidia occurred evenly as single cells on the grape berry surface and seldom landed at the wound periphery. They remained dormant on dry berries, but germinated freely on the unbroken skin and at the wound periphery on moist and wet berries. In the case of berries inoculated at bunch closure and harvest stages, wounds were not infected by conidia deposited on berries four days prior to wounding. This finding indicated that, following adhesion and the first stages of growth, the pathogen did not survive for extended periods on surfaces of immature and mature grape berries. Freshly deposited dry conidia were needed to infect the wounds. The freshly deposited conidia furthermore needed free water, and not high humidity or wound exudates, to infect the fresh wounds. Proportions of wounds infected were extremely low. According to these findings, this mode of infection should not contribute to a gradual build-up of secondary inoculum and to $B$. cinerea epiphytotics in the vineyard. The previously and freshly deposited conidia both infected wounds made on cold-stored mature berries. Of the two inocula, freshly deposited conidia were more successful in causing wound infection. Therefore, in the event of wounding, postharvest decay would be caused primarily by conidia occurring on the grape berry surface, and not by mycelia in the berry skin.
\end{abstract}

Botrytis bunch rot, caused by Botrytis cinerea, is an economically important disease of grapevine (Vitis vinifera L.). The pathogen occurs in vineyards as sclerotia (Nair \& Nadtotchei, 1987), conidia (Corbaz, 1972; Bulit \& Verdu, 1973) and mycelia (Gessler \& Jermini, 1985; Northover, 1987). Conidia are the primary inoculum for infection of berries on which the most prominent phase of the disease is found (Nair \& Nadtotchei, 1987; Nair \& Hill, 1992). Different infection pathways have been described for $B$. cinerea on grape berries, namely through stigmata (McClellan \& Hewitt, 1973; Nair \& Parker, 1985), pedicels (Pezet \& Pont, 1986; Holz, Coerze \& Basson, 1997; Holz, Coertze \& Basson, 1998), natural openings (Pucheu-Planté \& Mercier, 1983), wounds (Nair, Emmett \& Parker, 1988), or by direct penetration of the cuticle (Nelson, 1956; Coertze \& Holz, 1999; Coertze, Holz \& Sadie, 2001). Of these, wounds have been regarded as a major pathway (Du Plessis, 1937; Hill et al., 1981; Nair et al., 1988).

Conidia of $B$. cinerea are deposited on berry surfaces primarily from airborne inoculum or in water (Jarvis, 1962a, 1962b). Observations made in vineyards showed that airborne conidia are deposited as single cells on spore traps (G. Holz, unpublished data). Few of the $B$. cinerea conidia dispersed by raindrops become wet enough to enter the droplets, and the majority are carried on the droplet surface as a dry coating (Jarvis, 1962b). Raindrops may therefore deposit conidia carried on their surfaces as single cells onto berry surfaces during runoff. Washings made from grape berries in Californian (Duncan, Stapleton \& Leavitt, 1995) and South African vineyards (G. Holz, unpublished data) substantiated these observations. The amount of $B$. cinerea on berry surfaces was low throughout the season, and $B$. cinerea occurred as single colony-forming units. Conidia of $B$. cinerea attach in two distinct stages to hydrophobic surfaces (Doss et al., 1993; Doss et al., 1995). Immediate adhesion occurs upon hydration of freshly deposited conidia, whereas stronger delayed adhesion occurs as conidia start to germinate. Conidia of $B$. cinerea adhere more strongly when applied in water suspension or to the wet surface of grape berries than when dry conidia are applied to a dry surface (Spotts \& Holz, 1996). Conidia or germlings adhering to the cuticle are not easily dislodged from grape berry surfaces (Spotts \& Holz, 1996). These findings imply that, following air and water dispersal, infection by solitary conidia, and not by conidial clusters, should play a prominent role in the epidemiology of the disease (Coertze \& Holz, 1999; Holz et al., 2000; Coertze et al., 2001). Furthermore, external forces cannot easily redistribute conidia or germlings adhering to the berry skin to fresh wounds. Therefore, to infect a wound in the grape skin, newly arrived conidia should land in or near the wound and grow into the wound under the prevailing conditions. On the other hand, in the event of wounding, propagules of $B$. cinerea may occur in various growth stages at the wound site. Firstly, there may be conidia in a dormant state adhering to the skin. Secondly, there may be germlings that had colonised but had not penetrated 
the skin. Thirdly, there may be germlings that had penetrated the skin, but were localised by host defence. In the case of dormant conidia adhering on a dry berry, wounding should be near a conidium, thereby breaking the cuticle and supplying the conidium with the necessary moisture and nutrients to germinate and to infect. In the case of germlings that had only colonised the berry surface, wounding should be near the growing germ tube or hyphae, thereby opening up an avenue for penetration or supplying the germling with the necessary moisture and nutrients. In the case of a germling that had penetrated the skin, but was localised by host defence, wounding should be near the germling, an action that should terminate the host resistance and supply the established pathogen with the necessary nutrients to escape the host defence barrier and cause the berry to rot.

The potential infectivity of single airborne conidia of $B$. cinerea on grape berries at different phenological stages was described recently (Coertze \& Holz, 1999; Coertze et al., 2001). Microscopic observations (Coertze et al., 2001) on grape berry surfaces showed that dry conidia seldom land on stomata, lenticels or microcracks in the cuticle. Following deposition, dry airborne conidia usually germinate within $3 \mathrm{~h}$ on the surface of both moist and wet grape berries (Coertze \& Holz, 1999). Their germination was influenced by wetness and grape phenology, and they always penetrated the grape skin directly, irrespective of wetness regime or berry ripeness. Wetness and grape phenology also regulated conidium and germling dieback. Different patterns of dieback were furthermore observed amongst individuals on a given berry. This behaviour of airborne conidia indicated that time of wounding in relation to arrival of inoculum at the wound site, wetness and berry ripeness may influence wound infection of grape berries in the vineyard. This study describes infection of wounds on berries exposed to freshly deposited airborne conidia, and of wounds on berries carrying previously deposited conidia and germlings (latent infections). Fresh (immature and mature) and cold-stored grapes (mature), which are respectively highly resistant and highly susceptible to infection and symptom expression by single airborne conidia of $B$. cinerea (Coertze \& Holz, 1999; Coertze et al., 2001), were included in the study.

\section{MATERIALS AND METHODS}

\section{Grapes}

Grape bunches (cultivar Dauphine) were selected at bunch closure $\left(6.3^{\circ}\right.$ Brix $)$ and at harvest $\left(16.6^{\circ}\right.$ Brix $)$ from a vineyard with a history of low $B$. cinerea disease incidence. Mature grapes were used after harvest, or after a 3- to 4-wk period of cold storage at $-0.5^{\circ} \mathrm{C}$. Bunches for cold storage were packed with an $\mathrm{SO}_{2}$ generator (0.3$0.55 \mathrm{~g} \mathrm{Na}_{2} \mathrm{~S}_{2} \mathrm{O}_{5}$ affixed to a paper sheet [Laszlo et al., 1981; Nelson, 1983]) inside a polyethylene bag in corrugated boxes (Patent no. RSA 75/6116). Following harvest, or cold storage, the bunches were surface-disinfested (30 sec in 70\% ethanol, 2 min in $0.35 \%$ sodium hypochlorite, $30 \mathrm{sec}$ in $70 \%$ ethanol) and air-dried. This treatment completely eliminated $B$. cinerea from the berry surface (Sarig et al., 1996) and prevented natural infection (Coertze \& Holz, 1999). Berries were cut from clusters with short stem segments attached and packed on sterile epoxy-coated steel mesh screens ( 53 by 28 by $2 \mathrm{~cm}$ ). To recognise the inoculated side of the berry at a later stage, a 1-cm mark was made on the berry near the pedicel with a felt-tipped pen. Previous studies (Coertze $\&$ Holz, 1999) showed no phytotoxic effect of the ink on berries.

\section{Wounding}

Wounds were made on the marked side of the berry with a woundmaker, consisting of a cork stopper, dome shaped to fit onto the berry cheek, through which five needles protruded in a cris-cross pattern. The needles were $5 \mathrm{~mm}$ apart and inflicted wounds approximately $0.8 \mathrm{~mm}$ in diameter and $1.5 \mathrm{~mm}$ deep. After each wounding, the woundmaker was sterilised by pressing it for $5 \mathrm{sec}$ onto an ethanol drenched cottonwool swab.

\section{Inoculation}

A virulent isolate of $B$. cinerea (Coertze \& Holz, 1999), obtained from a naturally infected grape berry, was maintained on potatodextrose agar (PDA) at $5^{\circ} \mathrm{C}$. For the preparation of inoculum the isolate was first grown on canned apricot halves. Conidiophores from the colonised fruit were transferred to PDA in Petri dishes and incubated at $22^{\circ} \mathrm{C}$ under a diurnal regime ( $12 \mathrm{~h}$ near-ultraviolet light). Conidia were harvested dry with a suction-type collector from 14-day-old cultures and stored dry at $5^{\circ} \mathrm{C}$ for 1 to 16 weeks. Storage time did not affect germination (Spotts \& Holz, 1996) and the dry conidia could therefore be used in all experiments. For inoculation $3 \mathrm{mg}$ dry conidia were dispersed by air pressure into the top of an inoculation tower (Plexiglass, 3 by 1 by $1 \mathrm{~m}=$ height by depth by width) according to the method of Salinas et al. (1989) and allowed 20 min to settle onto the berries, which were positioned on two screens on the floor of the tower. At this dosage approximately three conidia were evenly deposited as single cells on each $\mathrm{mm}^{2}$ of berry surface (Coertze \& Holz, 1999). Petri dishes with water agar (WA) and PDA were placed on the floor of the settling towers at each inoculation and percentage germination of conidia was determined after $12 \mathrm{~h}$ incubation at $22^{\circ} \mathrm{C}$ (100 conidia per Petri dish, three replicates). Germination was between 91 and $99 \%$ at $12 \mathrm{~h}$ post-inoculation for all experiments.

In the fresh wound/fresh conidia experiment berries were inoculated $1 \mathrm{~h}$ after wounding. Following inoculation, the screens were placed in 9 ethanol-disinfected perspex (Cape Plastics, Cape Town, South Africa) chambers ( 60 by 30 by $60 \mathrm{~cm}$ ). Each chamber contained one screen and 30 berries were placed on each screen. Each chamber was considered an experimental block. Six of the chambers were lined with a sheet of chromatography paper with the base resting in deionised water to establish high relative humidity ( $\geq 93 \% \mathrm{RH}$ ). In three of these chambers the berries were overlaid with sterile paper towels wetted with sterile, deionised water. Berries in the other three chambers were kept dry (40-50\% $\mathrm{RH})$. These conditions provided three wetness regimes: dry conidia on dry berries under dry conditions (dry berries); dry conidia on dry berries under high relative humidity (moist berries); and dry conidia exposed to a film of water on the berry surface (wet berries). The chambers were kept at $22^{\circ} \mathrm{C}$ for $24 \mathrm{~h}$ with a $12 \mathrm{~h}$ photoperiod daily. Studies (Coertze et al., 2001) with airborne conidia of $B$. cinerea on grape berries under similar wetness regimes showed that germination and surface colonisation reached a maximum during this period. After $24 \mathrm{~h}$ the screens were removed from the different chambers, the paper towels were removed and the berries air-dried before they were placed in dry chambers (40$50 \% \mathrm{RH}$ ) and kept at $22^{\circ} \mathrm{C}$. The experiment was repeated.

In the fresh wound/previously deposited conidia/germling experiment, berries were inoculated and kept at the three wetness 
regimes for $24 \mathrm{~h}$ as described previously. The screens were removed from the different chambers and kept for $72 \mathrm{~h}$ at $22^{\circ} \mathrm{C}$ in dry chambers $(40-50 \% \mathrm{RH})$. This period allowed for conidium attachment, germination, surface colonisation, penetration, activation of active defence and localisation of established infections, and germling dieback (Coertze et al., 2001). The berries were wounded and kept at $22^{\circ} \mathrm{C}$ in dry chambers to promote the pathogens' development. The experiment was repeated.

\section{Histology}

Two berries were randomly selected at set stages from each screen per chamber and examined for exudates from wounds, conidial germination, surface colonisation, wound penetration and wound healing. Exudates at wound sites were examined $1 \mathrm{~h}$ after wounding by observing berries under a dissecting microscope. Germination, surface colonisation, wound penetration and wound healing were examined 3 and 5 days after wounding using fluorescence microscopy. Thin pieces $(10 \times 5 \mathrm{~mm})$ of skin consisting of the wounded area were cut from the berries with a razor blade. Fluorescein diacetate $(2 \mathrm{mg}$ per $\mathrm{mL}$ acetone; SigmaAdrucg, St Louis) and aniline blue $\left(0.1 \%\right.$ in $\mathrm{KH}_{2} \mathrm{PO}_{4}$ buffer, $\mathrm{pH}$ 5.0; BDH Laboratory Chemicals Division, Poole, England) were prepared as stock solutions and stored at $-20^{\circ} \mathrm{C}$ and $5^{\circ} \mathrm{C}$, respectively. Before a histology session, blankophor $(0.5 \%$; Bayer, Germany) was added to the aniline blue solution and a fresh stain was prepared by mixing $25 \mu \mathrm{L}$ of the fluorescein diacetate stock solution with $1 \mathrm{~mL}$ of the aniline blue-blankophor stock solution in a $1.5-\mathrm{mL}$ polypropylene tube, which was then kept on ice. The sections were stained for $5 \mathrm{~min}$, mounted on a glass slide in 0.1 $\mathrm{M} \mathrm{KH}_{2} \mathrm{PO}_{4}$ buffer ( $\mathrm{pH}$ 5.0) and covered with a cover slip. Fungal structures and wound healing were examined with a Zeiss Axioskop microscope equipped with an epifluorescence condenser, a high-pressure mercury lamp, Neofluar objectives and Zeiss filters 02,06 and 18 . These sets include excitation filters $G$ 365 , BP $436 / 8$ and BP 395-425, respectively. With this configuration protoplasts of viable fungal structures fluoresced brilliant yellow-green with filters 02,06 and 18. Protoplasts of dead cells were blue-black (filters 06 and 18), whereas cells without protoplasts fluoresced white (filter 02) or yellow (filter 18) (O'Brien \& McCully, 1981). Formation of stilbenes became visible by irradiation with UV light (filter 02), resulting in a bright blue fluorescence (Langcake, 1981). Suberised cell walls fluoresced a light blue or bright yellow (Hill, 1985b; Holloway \& Wattendorf, 1987; Brown, 1989; Ippolito et al., 1997). Wound healing became visible due to stilbene accumulation, as well as lignification and suberisation of surrounding cell walls.

\section{Assessment of wound infection}

The remaining berries were examined daily for decay development at or away from the wound site, and the number of wounds that developed decay per treatment was recorded. The mean number of wounds out of a potential 120 infected by $B$. cinerea 14 days after inoculation was calculated, and the data were used to describe wound infection for each treatment.

\section{Statistical analysis}

The experimental design was a complete randomised block with six replications, consisting of treatments according to a $3 \times 2 \times 3$ factorial design (phenological stage $\mathrm{x}$ treatment $\mathrm{x}$ wetness regime). A four-way analysis of variance with experiment, growth stage, treatment and wetness regime as factors was performed on the data. Statistical computations were performed using SAS (SAS Institute Inc., Cary, NC). Data were tested for normality and homogeneity of variance prior to analysis. Data from each experiment were analysed as raw proportions. Significant effects $(P \leq 0.05)$ were examined with Student's $t$-test (Snedecor \& Cochran, 1980).

\section{RESULTS}

\section{Histology}

Within the 1-h period after wounding, exudates from wounds exuded onto a small fringe of the surrounding skin, then withdrew leaving a demarcated residue. On berries at bunch closure stage $49 \%$ of the wounds produced an exudate, which covered a distance of between 0.05 to $0.09 \mathrm{~mm}$ from the wound periphery. On ripe berries $78 \%$ of the wounds produced an exudate which covered a distance of between 0.08 to $0.15 \mathrm{~mm}$. On cold-stored berries $96 \%$ of the wounds produced an exudate which covered a distance of between 0.12 to $0.3 \mathrm{~mm}$. On berries at bunch closure and the ripe stage a darkening developed after 3 days in cells underlying the cuticle surrounding wounds, and in cells in the wound cavity. The dark zone was very prominent after 5 days. Fluorescence microscopy revealed extensive stilbene, suberin and lignin accumulation in the cells and cell walls underlying the cuticle surrounding the wound and in the wound cavity. Wound healing was more pronounced on berries kept under humid or wet conditions than on berries kept dry, and also on berries at bunch closure than the ripe stage. On cold-stored berries cells at the periphery of a minority of the wounds revealed stilbene, suberin and lignin accumulation. This response was not shown by cells in the wound cavity. Conidia occurred evenly as single cells on the grape berry surface and seldom landed at the wound periphery. They remained dormant on dry berries, but germinated freely on the unbroken skin and at the wound periphery of moist and wet berries. On moist berries germ tubes of germlings growing at the wound periphery were too short to enter the wound. On wet berries germ tubes or hyphae that grew in the vicinity of wounds were not attracted by wounds. Only one successful penetration was observed on cold-stored berries. On berries with previously deposited conidia and germlings, none of the germlings in the wound vicinity showed regrowth following wounding. Furthermore, none of the berries examined had fungal growth in the wound cavity.

\section{Wound infection}

Overall, in the fresh wound/fresh conidia experiment, $6.7 \%$, $10.6 \%$ and $35.2 \%$ of the berries developed $B$. cinerea rot at bunch closure, harvest and after cold storage, respectively. Values for the three growth stages in the fresh wound/previously deposited coni$\mathrm{dia}$ /germling experiment were $0 \%, 0.9 \%$ and $1.9 \%$, respectively. Decay on berries yielding $B$. cinerea rot invariably originated at a wound. Furthermore, on nearly all infected berries, only one out of five wounds developed decay. On berries at bunch closure decay was confined to the wound, depressed and lesions were sharply demarcated. Lesions on ripe berries were brown, superficial and decay development was restricted. Lesions on coldstored berries were light brown, superficial and spread rapidly.

The variance in mean number of wounds that developed decay in the two experiments was small, indicating homogeneity in the 
month at 80 percent of the weather stations and because most grapes in the Western Cape ripen during February and March. In a trial where Sauvignon blanc was grown in regions with different macro-climates (Stellenbosch, Elgin, Robertson), a "cool climate" and a "warm climate" wine style could be identified (Marais, Hunter \& Haasbroek, 1999). The principal shortfall of the early climatic maps (Le Roux, 1974; De Villiers et al., 1996) was that the distances between weather stations were too great for data to be reliably interpolated between them. Over the past decade, however, the network of weather stations has been progressively expanded. Intensive recording of climatic data, such as that which is now available for the Bottelary-SimonsbergHelderberg wine-growing area, has shown that, even within areas with a uniform macro- climate, certain aspects of climate may vary considerably (Carey, 2001). In order to gain further information on genotype/climate interactions, and the effects of such interactions on wine character, reference plots in close proximity to the weather stations were monitored (Carey et al., 2001). The effect of season and site climates on the aroma profile of the wines was clear for all three cultivars (Sauvignon blanc, Chardonnay and Cabernet Sauvignon). However, the effect of soil water status on aroma profile was not taken into account in this study (Carey et al., 2001).

\section{Geology}

Apart from the indisputable effect of climate on wine character, geology is considered to have a potential predetermining effect on wine character and quality (Wilson, 1998). Geology was the primary key to identify the "Unités Terroir de Base" in the MidLoire Valley in France (Morlat, 1996). There is, however, no individual geological formation that results in wine of high quality (Seguin, 1983) and grapevines are found on many geological formations. The effects of geology on wine quality are not direct, since it is mainly the physical properties of a soil that determine quality through the effects of such variables as drainage, soil temperature and water availability on vine growth patterns. The indirect effects of past geological processes on vineyard performance may be profound, since such processes created the materials which weathering has sculpted to form the modern landscape.

In the Stellenbosch/Durbanville region of South Africa soils developed from a variety of geological materials. The oldest rocks are sedimentary formations of the Malmesbury Group. These include shales, schist, phyllite and greywacke (Theron et $a l .$, 1992). In late pre-Cambrian times the Malmesbury sediments were folded into a mountain chain and intruded by granites of the Cape Granite Suite. This landscape eventually subsided and was covered by the thick sequence of sands and shales which make up the Cape Supergroup. Erosion subsequently stripped the Cape Supergroup from much of what is now the coastal plain of the Western Cape, once again exposing the pre-Cape floor with its low granite hills and occasional, steep-sided remnants of the Table Mountain Group. Most vineyards occupy low or intermediate positions in the landscape, at altitudes which range from 10$500 \mathrm{~m}$. Few of the vineyard soils in the Coastal Wine-growing Region were derived by in situ weathering of the underlying rock formations. Long continued transport and reworking at these low altitudes led to the formation of soil parent materials which contain mineral material derived from a number of rock types. In a recent study (Van Schoor, 2001) it was not possible to relate par- ent material directly to grapevine growth, wine quality and/or wine character. No other studies on the effect of geology on grapevine performance have been reported from South Africa.

\section{Soil type}

Research in Bordeaux (Seguin, 1983) showed that classified vineyards owe their superiority to the ability of soil to regulate the supply of water to the vines, rapidly draining excessive water but retaining sufficient water, and delivering it at such a rate that, although the vines experience some stress towards ripening, this stress is not excessive. Soil type was found to be a poor guide to vine performance and wine quality, unless considered in conjunction with climate, cultural practices and the specific requirements of individual cultivars. On account of soils and climate being vastly different, models developed in Europe cannot be applied directly to South Africa. According to Rankine et al. (1971), soil plays a subordinate role to climate in terms of its effects on wine quality in warm regions. In South Africa, however, soil may have a pronounced effect, as was shown by Saayman (1977), who found that the characteristics of Cinsaut wines varied according to the soil type on which the vines were grown, even when meso-climatic conditions were the same. Since 1977 no further scientific studies on the effect of soil type on grapevine performance have been reported in South Africa.

\section{Nutrient status of soil}

In South African vineyard soils the two elements which may have a definite effect on wine quality are nitrogen and potassium, assuming that there are no serious deficiencies of the other essential elements (Saayman, 1992). Excessive nitrogen delays ripening, enhances the occurrence of bunch rot and stimulates unwanted growth, resulting in unbalanced and herbaceous wines. Insufficient nitrogen, on the other hand, may result in decreased yields and musts with too little assimilable nitrogen, thus contributing to retarded or stuck fermentation (Gladstones, 1992 and references therein). The extent to which a specific soil will be able to supply nitrogen to grapevines will be largely dependent on its organic material content (Conradie, 1986). As the organic material content of a soil is normally related to climate (Stevenson, 1986), largely different nitrogen-supplying capacities can be expected for different terroirs. It is a well-recognised fact that soil-K levels may have a considerable effect on the acid balance in grape juice and on the $\mathrm{pH}$ of the resulting wine (Conradie \& Saayman, 1989), while the response of grapevines to soil potassium will also be affected by other factors, such as the clay content of the soil, potassium saturation of the exchange complex and $\mathrm{K} / \mathrm{Mg}$ ratios in the soil (Etourneaud \& Loué, 1984). Here geology does play a role, in the sense that a large percentage of vineyard soils in the Western Cape are derived from granite, which is relatively rich in potassium-containing minerals (Visser, 1964; Wooldridge, 1988). Kaolinic, granite-derived soils have a low buffering capacity for potassium and have been shown to promote luxurious consumption of potassium in grasses (Wooldridge, 1988). Grapevines may also consume excessive amounts of potassium from chemically weathered granitic soils. However, luxurious consumption of potassium will also be induced by excessive fertilisation.

\section{Scope of current study}

Because scientific data on the demarcation of terroir units is limited in South Africa, a study was undertaken at selected localities 
representing different landscape positions and underlain by contrasting rock types in the Stellenbosch/Durbanville districts. These districts currently contain $17 \%$ of South Africa's vineyards (SAWIS, 2000). Sauvignon blanc, being the most important cultivar for production of high-quality white wines in these districts, was used as test material. The hypothesis was that soil type may play an important role in determining wine characteristics, resulting in different wine styles for different soils, even under identical meso-climatic conditions. The ultimate goal was to identify sets of conditions (climate, landscape position, altitude, soil, etc.) that will lead to wines with specific styles. As a preliminary step towards this goal the first objective of the current study was to quantify differences in meso-climate at the selected localities. The second objective was to identify two different soil forms at each locality. Physical and chemical characteristics of soils were to be determined, while soil and plant water status were to be monitored on a regular basis. Thirdly, the interaction between climate, landscape position, geology and soil characteristics, as manifested in grapevine performance, was to be determined. The present article is limited in scope to phenology, growth, yield and chemical composition of grapes. If localities and soils can be separated in terms of the above-mentioned parameters, it should be possible to produce, within the Stellenbosch/Durbanville districts, a range of Sauvignon blanc wines with region-specific characteristics. Differences in actual wine quality will then become the subject of a separate article.

\section{MATERIALS AND METHODS}

The study was carried out over seven seasons (1994/1995 to 2000/2001) in five commercial Sauvignon blanc vineyards. All were within a radius of $15 \mathrm{~km}$, four situated in the district of Stellenbosch and one in Durbanville (Fig. 1). Their co-ordinates, altitudes, aspects, slopes and distances from the sea are summarised in Table 1. The soils at Kuils River are underlain (Theron et al., 1992; Van Schoor, 2001) by the Kuils River-Helderberg Granite pluton. Both Papegaaiberg and Devon Valley are situated on hornfels, which was formed when the Kuils River-Helderberg Granite pluton intruded into Malmesbury sediments. As in the

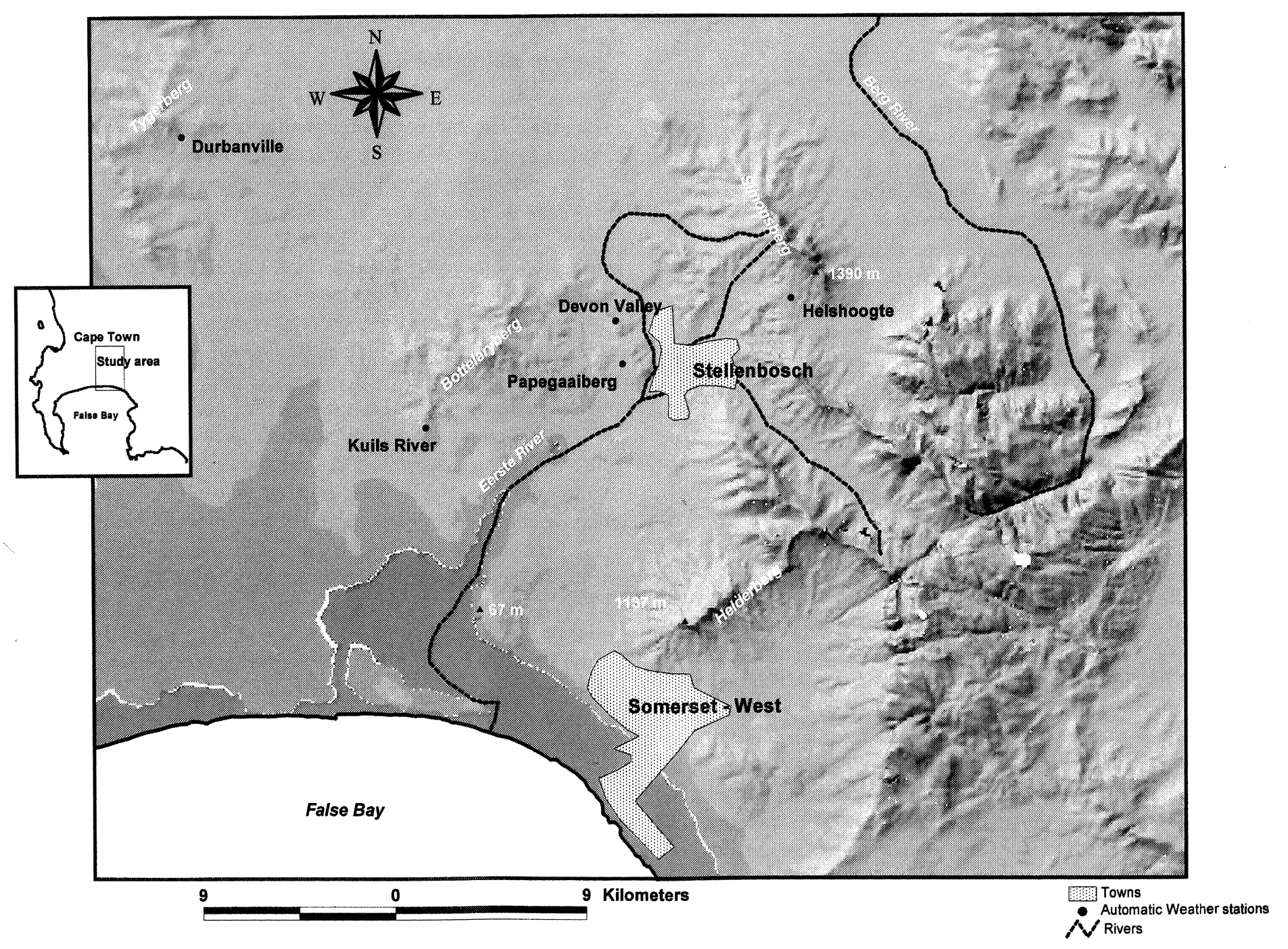

FIGURE 1

Study area and locations of the experimental sites. 
TABLE 1

Characteristics of the five experimental localities, all planted to Sauvignon blanc/99 Richter.

\begin{tabular}{|c|c|c|c|c|c|c|c|c|c|}
\hline Locality & Coordinates & $\begin{array}{l}\text { Altitude } \\
\quad(\mathbf{m})\end{array}$ & Aspect & $\begin{array}{l}\text { Slope } \\
(\%)\end{array}$ & $\begin{array}{l}\text { Distance } \\
\text { from } \\
\text { False Bay } \\
\quad(\mathbf{k m})\end{array}$ & $\begin{array}{l}\text { Distance } \\
\text { from } \\
\text { Table Bay } \\
\quad(\mathbf{k m})\end{array}$ & $\begin{array}{l}\text { Geological } \\
\text { formation }\end{array}$ & $\begin{array}{l}\text { Soil } \\
\text { form }\end{array}$ & Description \\
\hline \multirow[t]{2}{*}{ Kuils River } & \multirow[t]{2}{*}{$\begin{array}{l}33^{\circ} 57^{\prime} 18^{\prime \prime} \mathrm{S} \\
18^{\circ} 44^{\prime} 05^{\prime \prime} \mathrm{E}\end{array}$} & \multirow[t]{2}{*}{250} & \multirow[t]{2}{*}{ ESE } & \multirow[t]{2}{*}{14.5} & \multirow[t]{2}{*}{13} & \multirow[t]{2}{*}{24} & \multirow{2}{*}{$\begin{array}{l}\text { Kuils River - } \\
\text { Helderberg } \\
\text { Granite pluton }\end{array}$} & Tukulu & $\begin{array}{l}\text { Light textured, gravelly topsoil, mottled, high- } \\
\text { ly weathered subsoil, with signs of wetness }\end{array}$ \\
\hline & & & & & & & & Vilafontes & $\begin{array}{l}\text { Medium textured, gravelly topsoil, medium } \\
\text { textured subsoil }\end{array}$ \\
\hline \multirow[t]{2}{*}{ Papegaaiberg } & \multirow[t]{2}{*}{$\begin{array}{l}33^{\circ} 55^{\prime} 46^{\prime \prime} \mathrm{S} \\
18^{\circ} 50^{\prime} 06^{\prime \prime} \mathrm{E}\end{array}$} & \multirow[t]{2}{*}{148} & \multirow[t]{2}{*}{ NW } & \multirow[t]{2}{*}{5.7} & \multirow[t]{2}{*}{18} & \multirow[t]{2}{*}{33} & \multirow[t]{2}{*}{ Hornfels } & Avalon & $\begin{array}{l}\text { Medium textured, yellow-brown, weakly } \\
\text { structured, mottled subsoil }\end{array}$ \\
\hline & & & & & & & & Tukulu & $\begin{array}{l}\text { Medium textured, yellow-brown, weakly } \\
\text { structured, signs of wetness in subsoil }\end{array}$ \\
\hline \multirow[t]{2}{*}{ Devon Valley } & \multirow[t]{2}{*}{$\begin{array}{l}33^{\circ} 54^{\prime} 44^{\prime \prime} \mathrm{S} \\
18^{\circ} 49^{\prime} 55^{\prime \prime} \mathrm{E}\end{array}$} & \multirow[t]{2}{*}{200} & \multirow[t]{2}{*}{ WNW } & \multirow[t]{2}{*}{6.4} & \multirow[t]{2}{*}{20} & \multirow[t]{2}{*}{32} & \multirow[t]{2}{*}{ Hornfels } & Oakleaf & $\begin{array}{l}\text { Medium textured, yellow-brown, weakly } \\
\text { structured }\end{array}$ \\
\hline & & & & & & & & Glenrosa & $\begin{array}{l}\text { Medium textured, yellow-brown, high } \\
\text { percentage stone }\end{array}$ \\
\hline \multirow[t]{2}{*}{ Helshoogte } & \multirow[t]{2}{*}{$\begin{array}{l}33^{\circ} 54^{\prime} 12^{\prime \prime} \mathrm{S} \\
18^{\circ} 55^{\prime} 15^{\prime \prime} \mathrm{E}\end{array}$} & \multirow[t]{2}{*}{413} & \multirow[t]{2}{*}{$\mathrm{S}$} & \multirow[t]{2}{*}{5.2} & \multirow[t]{2}{*}{24} & \multirow[t]{2}{*}{41} & \multirow{2}{*}{$\begin{array}{l}\text { Porphyritic biotite } \\
\text { granite of Stel- } \\
\text { lenbosch pluton }\end{array}$} & Tukulu & $\begin{array}{l}\text { Medium textured, yellow-brown, weakly } \\
\text { structured, slight signs of wetness with depth }\end{array}$ \\
\hline & & & & & & & & Hutton & $\begin{array}{l}\text { Medium textured, reddish-brown, very weakly } \\
\text { structured, well-drained }\end{array}$ \\
\hline \multirow[t]{2}{*}{ Durbanville } & \multirow[t]{2}{*}{$\begin{array}{l}33^{\circ} 50^{\prime} 00^{\prime \prime} \mathrm{S} \\
18^{\circ} 36^{\prime} 47^{\prime \prime} \mathrm{E}\end{array}$} & \multirow[t]{2}{*}{230} & \multirow[t]{2}{*}{$\mathrm{SE}$} & \multirow[t]{2}{*}{8.6} & \multirow[t]{2}{*}{27} & \multirow[t]{2}{*}{12} & $\begin{array}{l}\text { Phyllitic shales } \\
\text { (Tygerberg forma- }\end{array}$ & Westleigh & $\begin{array}{l}\text { Medium textured, dark colour, signs of water } \\
\text { table in winter }\end{array}$ \\
\hline & & & & & & & $\begin{array}{l}\text { tion of the Malmes- } \\
\text { bury group) }\end{array}$ & Tukulu & $\begin{array}{l}\text { Medium textured, dark coloured, weakly } \\
\text { structured, signs of wetness in subsoil }\end{array}$ \\
\hline
\end{tabular}

case of Kuils River, granite was the parent material at Helshoogte, but its origin (Stellenbosch pluton) was different. The soils at Durbanville originated from Malmesbury sediments, which form the oldest geological formation in the Western Cape.

Within each vineyard two contrasting soil forms (not more than $60 \mathrm{~m}$ apart) were identified (Table 1), using the South African Soil Classification System (Soil Classification Working Group, 1991). According to this system, soils are classified as a first category into soil forms, on the basis of the presence and properties of master horizons. Further classification into families is based on A, B and E horizon properties, degree of leaching, clay movement and wetness. Fairly large differences may therefore occur within a soil form.

In view of the study being conducted in commercial vineyards, with the prerequisite being different meso-climates/geological formations/soil types at the different localities, availability of sites was limited. Planting material (Sauvignon blanc / 99 Richter) was obtained from different commercial nurseries, implying that clones (both rootstock and scion) were not necessarily identical at the five selected localities. Managerial decisions at the studied sites (e.g. canopy management) also created limitations, which may have affected the outcome of this experiment. Planting density varied from $4000 /$ ha $(2.5 \mathrm{~m} \mathrm{x} 1.0 \mathrm{~m})$ at Kuils River, to $2778 / \mathrm{ha}$ ( $3 \mathrm{~m} \times 1.2 \mathrm{~m}$ ) at Durbanville. Vineyards were approximately 10 years old at the start of the investigation, were not irrigated, and were trained on vertical trellis systems (one wire for the cordon arms and two to four wires for the foliage). Experimental plots, consisting of two adjacent rows, with 10 adjacent vines each, were selected on each soil type. Vines were spur-pruned annually to 16 buds per meter cordon. Suckering (removal of shoots not located on spurs) was done before bloom. Apart from this, growers applied normal viticultural practices at each individual site. Topping ( $30 \mathrm{~cm}$ above the top wire) was usually done once or twice during the growing season. In the case of Durbanville some of the leaves in the bunch zone were also removed after veraison. According to the general practice for these districts, all soils had been delve ploughed to a depth of approximately $800 \mathrm{~mm}$ before grapevines were planted. During this process lime was also added, with the aim of increasing soil $\mathrm{pH}(\mathrm{KCl})$ to at least 5.5. Producers normally applied 30 $\mathrm{kg} \mathrm{N} / \mathrm{ha} / \mathrm{yr}$ (15 kg in spring and $15 \mathrm{~kg}$ post-harvest), while $\mathrm{P}$ and $\mathrm{K}$ were applied according to production.

Automatic weather stations (MC Systems, Cape Town) were erected halfway between the two plots at each locality and recorded temperature, rainfall, radiation, hours of sunshine, wind speed and direction every minute. These values were averaged or summed for the period of an hour and the hourly data set was used to calculate daily minimum, maximum and mean temperatures, number of hours with temperatures above $30^{\circ} \mathrm{C}$ and below $12^{\circ} \mathrm{C}$, growing degree-days (Amerine \& Winkler, 1944) and Huglin index (Huglin, 1978). Temperature variability indices for February were calculated according to Gladstones (1992). Plant water, available at the end of March $\left(\mathrm{PAW}_{\mathrm{e}}\right)$, was estimated as an 
index of water stress. In this approach, similar to the one formulated by Riou in 1994 and reported by Tonietto (1999), the following equation for seasonal water balance was used to calculate $\mathrm{PAW}_{\mathrm{e}}$ :

$\mathrm{PAW}_{\mathrm{e}}=\mathrm{PAW}_{\mathrm{b}}+\mathrm{P}-\mathrm{ET}$

where $\mathrm{PAW}_{\mathrm{b}}$ is the amount of water available in the $0-1.2 \mathrm{~m}$ soil layer at the beginning of the season (September), for each soil form. Soils were assumed to be at field capacity at the beginning of the season. $\mathrm{P}$ is total rainfall from September until March and ET is evapotranspiration over the same period. ET was calculated using mean monthly reference evapotranspiration $\left(\mathrm{ET}_{0}\right)$, measured at each locality over the seven seasons, and crop coefficients. The latter were calculated from the water consumption of dry land grapevines in Stellenbosch and mean monthly $\mathrm{ET}_{0}$ measured at Nietvoorbij in the Stellenbosch district (Myburgh, 1998). Where monthly rainfall exceeded ET for specific months (normally September/October) the "excess" (rainfall-ET) was regarded as drainage.

Leaf water potentials (pressure chamber technique of Scholander et al. (1965)) were measured once per week from November to March. Uncovered, fully mature sunlit leaves were used. Measurements were made on three leaves per experimental plot between 12:00 and 15:00. Changes in soil water content were measured weekly by means of a neutron probe at $300 \mathrm{~mm}$ depth intervals, down to a depth of $1500 \mathrm{~mm}$.

Studies on root distribution were carried out in 1993 by digging profile pits parallel to experimental rows. A root plot was done for each soil form, using the profile wall method of Böhm (1979). For the purpose of this study only two root classes were identified, i.e. fine $(\leq 1.0 \mathrm{~mm}$ diameter) or medium $(>1.0 \mathrm{~mm}$ diameter). Soils, sampled according to the different horizons identified, were analysed for $\mathrm{pH}(1: 2.5$ in $1 \mathrm{M} \mathrm{KCl}), \mathrm{P}$ (Bray No. 2 extract: $0.03 \mathrm{M} \mathrm{NH}_{4} \mathrm{~F}$ in $0.01 \mathrm{M} \mathrm{HCl}$ ), $\mathrm{K}, \mathrm{Ca}, \mathrm{Mg}$ and $\mathrm{Na}$ (all extracted with $1 \mathrm{M} \mathrm{NH} \mathrm{N}_{4} \mathrm{Cl}$ ), $\mathrm{CEC}$ (with $\mathrm{NH}_{4} \mathrm{Cl}$ at the $\mathrm{pH}$ of the soil) and organic $\mathrm{C}$ by the Walkley-Black method (Soil Classification Working Group, 1991). The water-holding capacities of the soils $(2.5 \mathrm{kPa}$ to $100 \mathrm{kPa}$ ) were measured on undisturbed soil cores, employing standard pressure-plate equipment. Bulk densities were also determined on undisturbed soil cores.

Dates of budburst, flowering and harvest were recorded annually for seven seasons (1994/95 to 2000/2001). Budburst was noted when $50 \%$ of the buds had reached stage 4 and flowering at stage 23 of the modified E-L system (Coombe, 1995). Cane mass, grape yield, bunch mass and berry mass were also determined. At harvest the musts were analyzed for soluble solid content $\left({ }^{\circ} \mathrm{B}\right)$, $\mathrm{pH}$ and total titratable acidity (expressed as $\mathrm{g} / \mathrm{L}$ tartaric acid). Grapes were harvested at optimal ripeness, which was considered to be at approximately $23^{\circ} \mathrm{B}$, at a titratable acidity of $8 \mathrm{~g} / \mathrm{L}$ and a $\mathrm{pH}$ of between 3.0 and 3.2.

Viticultural and climatic data were analysed statistically, using the seven seasons as replicates. Student's t LSD values were calculated to facilitate comparison between localities.

\section{RESULTS AND DISCUSSION}

\section{Physical analyses of soils}

Particle size distributions (depth weighted mean values) for the different soils are shown in Table 2. At Kuils River (granitic soils) the
Tukulu form contained less clay and more coarse sand in comparison to its Vilafontes counterpart. Normally coarser fragments are expected in soils derived from granite in comparison to those originating from Malmesbury rocks (Theron et. al., 1992), suggesting that the Tukulu may have been of purer granitic origin than the Vilafontes. The other granitic soils (Helshoogte) contained less coarse sand than the Kuils River soils, thus confirming that particle size distribution is not necessarily related to the underlying parent material. Greater mixing of parent materials or further advanced weathering must have occurred at Helshoogte than at Kuils River. For the hornfelsic soils (Papegaaiberg and Devon Valley), a higher proportion of finer sand, in comparison to coarser sand, was expected (Van Schoor, 2001). This was actually the case for the Oakleaf at Devon Valley, with very fine sand + fine sand $(29.4 \%)$ being more abundant than medium + coarse sand (11.6\%). For the other three hornfelsic soils, however, very fine sand + fine sand was found in a similar proportion to medium + coarse sand (Table 2). This could be ascribed to contributions from surrounding granitic material. Soils from Durbanville contained significantly more fine and very fine sand $(43.5 \%)$ in comparison to the other localities. This was expected, because the Durbanville soils are underlain by phyllitic shales, which weather into predominantly fine particles (Theron et al., 1992). Particle size analyses suggested that four of the soils (Tukulu at Kuils River, Oakleaf at Devon Valley and both at Durbanville) were related to underlying parent materials. The other six soils must have developed from admixtures of materials. This is a common phenomenon in the Western Cape.

Bulk densities were relatively high at Kuils River, Papegaaiberg and Devon Valley, compared to lower values at Helshoogte and Durbanville (Table 2). Higher organic material (Table 5) may have resulted in less compact soils at the latter two localities, but no clear pattern between parent material and bulk density could be detected.

Water-holding capacities were low for both soils at Kuils River (Table 2), due to low clay contents and high coarse sand fractions. Low water retention by the Tukulu at Papegaaiberg and the Glenrosa at Devon Valley, was on account of a high gravel content. In spite of a low clay content, water-holding capacity was relatively high for the Tukulu at Durbanville. This could be ascribed to high percentages of very fine sand + fine sand.

\section{Root distribution}

Results indicated that root distribution (Table 3), within a specific parent material, can be largely affected by factors such as soil moisture (either too wet or too dry), compacted layers and percentage stone. At Kuils River a light-textured topsoil, underlain by a light-textured subsoil with signs of wetness, could be identified for the Tukulu, in comparison to a medium-textured topsoil and a less wet subsoil for the Vilafontes (Table 1). The topsoil (0-300 $\mathrm{mm}$ ) of the Tukulu contained less than $7 \%$ of the total number of roots, probably on account of soil moisture being low during the largest part of the growing season. Medium roots were largely concentrated in the $300-600 \mathrm{~mm}$ layer, but fine root development was obviously enhanced by the slightly wet subsoil, resulting in fine roots being evenly distributed from $300 \mathrm{~mm}$ to $900 \mathrm{~mm}$. Total fine roots for the Vilafontes were more than double the number found for the Tukulu, while an appreciable number (20\% of total) was found in the more clayey topsoil. At Papegaaiberg (hornfels) the Tukulu soil again showed inferior root distribution in compar- 
ison to its Avalon counterpart, most likely on account of the higher gravel content and lower water-storage capacity (Table 2). For the second hornfelsic soil (Devon Valley) root distribution was better for the Oakleaf than the Glenrosa, due to a high stone frac- tion in the case of the Glenrosa. At Helshoogte (granite originating from the Stellenbosch pluton) root distribution was better for the wetter Tukulu soil than for the well-drained Hutton soil. The Hutton tended to be overly dry during the latter parts of the grow-

\section{TABLE 2}

Soil particle size distribution (\%), gravel content, bulk density and water-holding capacity for soils at five localities in Stellenbosch/ Durbanville districts (depth weighted means to a depth of $1000 \mathrm{~mm}$ ).

\begin{tabular}{|c|c|c|c|c|c|c|c|c|c|c|c|}
\hline Locality & Soil form & $\begin{array}{c}\text { Clay }^{(1)} \\
(<0.002 \mathrm{~mm})\end{array}$ & $\begin{array}{c}\text { Fine silt (1) } \\
(0.02- \\
0.002 \mathrm{~mm})\end{array}$ & $\begin{array}{c}\text { Coarse silt }{ }^{(1)} \\
(0.05- \\
0.02 \mathrm{~mm})\end{array}$ & $\begin{array}{l}\text { Very fine } \\
\text { sand }(1) \\
(0.10- \\
0.05 \text { mm })\end{array}$ & $\begin{array}{c}\text { Fine } \\
\text { sand }(1) \\
(0.25- \\
0.10 \mathrm{~mm})\end{array}$ & $\begin{array}{l}\text { Medium } \\
\text { sand (1) } \\
(0.50- \\
0.25 \text { mm })\end{array}$ & $\begin{array}{c}\text { Coarse } \\
\text { sand }{ }^{(1)} \\
(2.0- \\
0.50 \mathrm{~mm})\end{array}$ & $\begin{array}{c}\text { \% Gravel } \\
(>2.0 \mathrm{~mm})\end{array}$ & $\begin{array}{c}\text { Bulk } \\
\text { density } \\
\left(\mathbf{k g} / \mathbf{m}^{3}\right)\end{array}$ & $\begin{array}{c}\text { Water holding } \\
\text { capacity } \\
(\mathbf{m m} / \mathbf{m})\end{array}$ \\
\hline \multirow[t]{2}{*}{ Kuils River } & Tukulu & 8.0 & 11.3 & 6.7 & 8.0 & 14.9 & 12.5 & 37.1 & 37.2 & 1520 & 110 \\
\hline & Vilafontes & 20.4 & 11.7 & 5.5 & 7.2 & 15.0 & 11.7 & 27.1 & 30.6 & 1580 & 111 \\
\hline \multirow[t]{2}{*}{ Papegaaiberg } & Avalon & 32.4 & 8.0 & 5.3 & 10.2 & 16.0 & 13.6 & 11.5 & 5.0 & 1460 & 149 \\
\hline & Tukulu & 33.4 & 7.3 & 9.8 & 8.8 & 16.2 & 12.8 & 12.4 & 36.1 & 1670 & 118 \\
\hline \multirow[t]{2}{*}{ Devon Valley } & Oakleaf & 29.5 & 12.0 & 14.4 & 14.3 & 15.1 & 5.8 & 5.8 & 25.9 & 1594 & 147 \\
\hline & Glenrosa & 32.7 & 20.5 & 9.8 & 7.2 & 7.3 & 4.3 & 15.5 & 57.0 & (2) & $101^{(3)}$ \\
\hline \multirow[t]{2}{*}{ Helshoogte } & Tukulu & 30.6 & 14.5 & 10.1 & 8.4 & 11.5 & 9.2 & 14.0 & 9.8 & 1250 & 136 \\
\hline & Hutton & 31.8 & 12.8 & 8.4 & 8.7 & 14.1 & 10.7 & 11.7 & 8.9 & 1360 & 120 \\
\hline \multirow[t]{2}{*}{ Durbanville } & Westleigh & 19.4 & 13.1 & 13.7 & 19.1 & 17.3 & 7.1 & 3.9 & 3.4 & 1290 & 143 \\
\hline & Tukulu & 8.9 & 12.0 & 10.3 & 24.7 & 25.9 & 8.9 & 5.3 & 3.7 & 1320 & 120 \\
\hline
\end{tabular}

(1) Particle size analyses for soil fraction $<2 \mathrm{~mm}$, excluding gravel.

(2) Not determined.

(3) Water-holding capacity not determined due to high stone fraction. Estimated from value obtained for the Oakleaf.

\section{TABLE 3}

Effect of soil form on root distribution and root density of Sauvignon blanc/99 Richter at five different localities in Stellenbosch/ Durbanville districts.

\begin{tabular}{|c|c|c|c|c|c|c|c|c|c|}
\hline \multirow{3}{*}{ Locality } & \multirow{3}{*}{ Soil form } & \multicolumn{6}{|c|}{ Root distribution (\%) } & \multicolumn{2}{|c|}{$\begin{array}{c}\text { Root density in } 0-900 \mathrm{~mm} \text { soil } \\
\left.\text { layer (roots } / \mathrm{m}^{2}\right)\end{array}$} \\
\hline & & \multicolumn{3}{|c|}{ Fine roots $(\leq 1.0 \mathrm{~mm})$} & \multicolumn{3}{|c|}{ Medium roots $(>1.0 \mathrm{~mm})$} & \multirow[t]{2}{*}{$\begin{array}{l}\text { Fine roots } \\
(\leq 1.0 \mathrm{~mm})\end{array}$} & \multirow[t]{2}{*}{$\begin{array}{l}\text { Medium roots } \\
(>1.0 \mathrm{~mm})\end{array}$} \\
\hline & & 0-300 mm & $300-600 \mathrm{~mm}$ & $600-900 \mathrm{~mm}$ & 0-300 mm & $300-600 \mathrm{~mm}$ & $600-900 \mathrm{~mm}$ & & \\
\hline \multirow[t]{2}{*}{ Kuils River } & Tukulu & 6.5 & 44.8 & 48.7 & 6.7 & 74.1 & 19.0 & 232 & 58 \\
\hline & Vilafontes & 20.0 & 38.1 & 41.9 & 32.2 & 29.0 & 38.7 & 544 & 62 \\
\hline \multirow[t]{2}{*}{ Papegaaiberg } & Avalon & 25.3 & 39.3 & 35.4 & 26.4 & 31.5 & 42.1 & 863 & 140 \\
\hline & Tukulu & 26.8 & 31.8 & 41.4 & 15.7 & 48.7 & 25.6 & 261 & 160 \\
\hline \multirow[t]{2}{*}{ Devon Valley } & Oakleaf & 19.8 & 32.8 & 47.4 & 16.5 & 47.8 & 35.6 & 344 & 115 \\
\hline & Glenrosa & 30.1 & 32.5 & 37.4 & 21.0 & 37.1 & 41.9 & 246 & 105 \\
\hline \multirow[t]{2}{*}{ Helshoogte } & Tukulu & 38.0 & 25.5 & 36.5 & 28.2 & 42.3 & 29.4 & 561 & 170 \\
\hline & Hutton & 31.2 & 34.1 & 34.7 & 31.5 & 50.8 & 17.7 & 369 & 124 \\
\hline \multirow[t]{2}{*}{ Durbanville } & Westleigh & 22.6 & 38.7 & 38.7 & 21.1 & 25.0 & 53.8 & 106 & 52 \\
\hline & Tukulu & 36.7 & 34.1 & 29.3 & 33.0 & 38.7 & 28.3 & 581 & 106 \\
\hline
\end{tabular}


ing season. At Durbanville (phyllitic shales) root distribution was relatively poor for the Westleigh soil, probably on account of a water table during the first part of the growing season. In general, root distribution was not directly related to soil form, as illustrated by the fact that root density (total roots $/ \mathrm{m}^{2}$ ) within the Tukulu form ranged from 731 (Helshoogte) to 290 (Kuils River). Furthermore, relatively good root distribution was obtained for at least one soil from each individual parent material, suggesting that root distribution is only indirectly affected by parent material.

\section{Chemical analysis of soils}

No major differences in chemical analysis occurred between soils at the same locality (data not shown). Consequently only depthweighted mean values for the two soils at each locality are shown in Table 4. A relatively low $\mathrm{pH}$ value was found for the soils at Kuils River (Table 4), mainly on account of a value of 4.13 in the subsoil (650-1000 mm) (data not shown). At this locality, in contrast to the other four, lime was probably not adequately mixed into the subsoil during soil preparation. At $\mathrm{pH}$ values of 5.0 to 5.5 grapevine performance should not be seriously impeded (Conradie, 1983). None of the soils showed any signs of sodicity, as evidenced by the fact that $\mathrm{Na}$ saturation was never higher than $3 \%$. Phosphorous content ranged from $16.2 \mathrm{mg} / \mathrm{kg}$ (Papegaaiberg) to $48.3 \mathrm{mg} / \mathrm{kg}$ (Durbanville). In view of the fact that the $\mathrm{P}$ content of parent materials from the Western Cape tends to be low (Visser, 1964), these relatively high values must have been the result of $\mathrm{P}$ fertilisation. Grapevine performance should not be unduly impeded, either on account of $\mathrm{P}$ deficiency or P toxicity, at any of the concentrations shown in Table 4 (Saayman, 1981; Conradie \& Saayman, 1989).

The highest $\mathrm{Ca}$ level was found for Durbanville, thus being in agreement with a relatively high $\mathrm{pH}$ value. Potassium was highest for Papegaaiberg and lowest for Durbanville. Fertilisation practices may have had a significant effect on the $\mathrm{K}$ level of soils. If it is accepted that $\mathrm{K}$ content of the subsoil will be least affected by fertilisation, $\mathrm{K}$ levels in the deeper soil layers may be related to that of the parent material. This aspect will be discussed in the next section.

Both $\mathrm{S}$ value and CEC were highest for soils derived from Malmesbury shale (Durbanville). Since kaolinite, with a low CEC (White, 1987), is usually the predominant clay mineral in soils from the Western Cape (Van Schoor, 2001), the above results indicate that shale-derived soils contain a higher fraction of clay minerals with higher CEC values (e.g. illite and interstratified minerals). The highest $\mathrm{C}$ content was found for Helshoogte and Durbanville, suggesting higher levels of organic material in soils derived from Malmesbury shales and from the Stellenbosch Granite pluton in comparison to those originating from hornfels and from the Kuils River-Helderberg Granite pluton. However, the $\mathrm{C}$ content of soils is normally not related to parent material, but rather to prevailing climatic conditions during the process of soil formation (Stevenson, 1986), thus implying that soils at Helshoogte and Durbanville were formed under cooler conditions. Vineyard soils from the Stellenbosch region should be capable of supplying sufficient $\mathrm{N}$ to satisfy the demand of grapevines, where the organic material content exceeds $1 \%$ (Conradie, 1986). This suggested that the standard $\mathrm{N}$ fertilisation programme for this region $(30 \mathrm{~kg} \mathrm{~N} / \mathrm{ha} / \mathrm{yr}$ ) could be waived at Helshoogte and at Durbanville.

\section{Potassium in subsoil}

The lowest value $(18 \mathrm{mg} / \mathrm{kg})$ for $\mathrm{K}$ in the subsoil $(600-1000$ $\mathrm{mm}$ ) was found at Durbanville (Table 5), thus being in agreement (Visser, 1964; Wooldridge, 1988) with the fact that shales contain less total potassium than granite (Kuils River and Helshoogte). However, since hornfels contains even less $\mathrm{K}$ than phyllitic shales, high potassium levels at Papegaaiberg and Devon Valley did not correlate with parent material. These high levels may have been derived from $\mathrm{K}$ fertilisers that leached into the subsoil or they may have been the result of mixing of parent materials. Relatively high clay contents at both these localities (Table 2) could have impeded leaching of $\mathrm{K}$ to some extent, thus pointing more towards mixing of parent materials. At Kuils River, where clay content was low (Table 2), potassium may have leached into the subsoil, thus explaining a relatively high value in comparison to the other granitic soil (Helshoogte). Basically the above results were in agreement with the suggestion that management practices can change the chemical composition of soils to such an extent that they no longer have their original characteristics (Seguin, 1986). In general, with Durbanville being the only exception, potassium levels of subsoils could not be related to underlying geological formations, thus suggesting that this parameter cannot be used to decide on the merits of a specific terroir.

\section{Climate}

The macro-climate in the Stellenbosch/Durbanville districts can be classified as Mediterranean, i.e. mild, rainy winters and warm,

\section{TABLE 4}

Chemical characteristics of soils $(0-1000 \mathrm{~mm})$ at five localities in Stellenbosch/Durbanville districts (depth weighted means for two soils at each locality).

\begin{tabular}{|c|c|c|c|c|c|c|c|c|c|c|c|}
\hline Locality & $\underset{(\mathbf{K C l})}{\mathbf{p H}}$ & $\begin{array}{l}\text { Resistance } \\
\text { (ohm) }\end{array}$ & $\begin{array}{c}\mathrm{P} \\
(\mathrm{mg} / \mathrm{kg})\end{array}$ & $\begin{array}{c}\text { Ca } \\
(\mathrm{meq} / 100 \mathrm{~g})\end{array}$ & $\begin{array}{c}\text { Mg } \\
(\mathrm{meq} / 100 \mathrm{~g})\end{array}$ & $\underset{(\mathrm{meq} / \mathbf{1 0 0 g})}{\mathrm{K}}$ & $\begin{array}{c}\mathrm{Na} \\
(\mathrm{meq} / \mathbf{1 0 0 g})\end{array}$ & $\begin{array}{c}\text { S value } \\
(\mathrm{meq} / 100 \mathrm{~g})\end{array}$ & $\begin{array}{c}\text { CEC } \\
(\mathrm{meq} / \mathbf{1 0 0 g})\end{array}$ & $\begin{array}{c}\text { Saturation } \\
(\%)\end{array}$ & $\begin{array}{c}\mathrm{C} \\
(\%)\end{array}$ \\
\hline Kuils River & $4.63 \mathrm{a}^{(1)}$ & $3299 \mathrm{~b}$ & $39.2 \mathrm{bc}$ & $1.74 \mathrm{a}$ & $0.87 \mathrm{ab}$ & $0.26 \mathrm{ab}$ & $0.008 \mathrm{a}$ & $2.88 \mathrm{a}$ & $4.69 \mathrm{a}$ & $61.4 \mathrm{a}$ & $0.49 \mathrm{a}$ \\
\hline Papegaaiberg & $5.03 \mathrm{~b}$ & $2566 a b$ & $16.2 \mathrm{a}$ & $1.75 \mathrm{a}$ & $0.71 \mathrm{ab}$ & $0.50 \mathrm{c}$ & $0.079 \mathrm{ab}$ & $3.04 \mathrm{a}$ & $4.99 \mathrm{a}$ & $60.9 \mathrm{a}$ & $0.58 \mathrm{a}$ \\
\hline Devon Valley & $5.33 \mathrm{bc}$ & $1934 \mathrm{a}$ & $33.9 \mathrm{bc}$ & $3.12 \mathrm{ab}$ & $1.78 \mathrm{~b}$ & $0.32 \mathrm{~b}$ & $0.041 \mathrm{a}$ & $5.26 \mathrm{ab}$ & $6.51 \mathrm{ab}$ & $80.8 \mathrm{ab}$ & $0.34 \mathrm{a}$ \\
\hline Helshoogte & $5.29 \mathrm{bc}$ & $3399 \mathrm{~b}$ & $23.7 \mathrm{ab}$ & $3.81 \mathrm{bc}$ & $0.54 \mathrm{a}$ & $0.27 \mathrm{ab}$ & $0.002 \mathrm{a}$ & $4.62 \mathrm{ab}$ & $6.19 \mathrm{ab}$ & $74.6 \mathrm{ab}$ & $1.15 \mathrm{~b}$ \\
\hline Durbanville & $5.42 \mathrm{c}$ & $1693 \mathrm{a}$ & $48.3 \mathrm{c}$ & $5.28 \mathrm{c}$ & $1.39 \mathrm{ab}$ & $0.21 \mathrm{a}$ & $0.243 \mathrm{~b}$ & $7.12 b$ & $7.96 \mathrm{~b}$ & 89.4 b & $1.29 \mathrm{~b}$ \\
\hline
\end{tabular}

(1) Values in columns followed by the same letter do not differ significantly $(\mathrm{p} \leq 0.05)$. 


\section{TABLE 5}

Potassium content of subsoil horizons $(600-1000 \mathrm{~mm})$ at five localities in Stellenbosch/Durbanville districts.

\begin{tabular}{lccc}
\hline Locality & $\begin{array}{c}\text { K } \\
(\mathbf{m e q} / \mathbf{1 0 0 g})\end{array}$ & $\begin{array}{c}\text { CEC } \\
(\mathbf{m e q} / \mathbf{1 0 0 g})\end{array}$ & $\begin{array}{c}\text { K saturation } \\
\mathbf{( \% )}\end{array}$ \\
\hline Kuils River & 0.179 & 4.64 & 3.86 \\
Papegaaiberg & 0.256 & 3.04 & 8.42 \\
Devon Valley & 0.231 & 6.59 & 3.50 \\
Helshoogte & 0.151 & 4.24 & 3.56 \\
Durbanville & 0.046 & 6.76 & 0.68 \\
\hline
\end{tabular}

dry summers. Mean data for the five weather stations for the seven-year period (1994-2001) are shown in Fig. 2. The coldest month (July) had a mean temperature of $12.1^{\circ} \mathrm{C}$, while $530 \mathrm{~mm}$ of rain (77\% of the annual total) was recorded from April to September. Dry conditions were experienced from December to March, with total summer (December-February) rainfall $(59 \mathrm{~mm})$, being less than $9 \%$ of the annual total. Temperature during the growing season placed the study area in region III of the Winkler degree-day classification (Winkler et al., 1974) with an index of 1783 degree-days. The value (2223 degree-days) for the Huglin Index (Huglin, 1978) indicated that there should be no heliothermic constraint for ripening of most cultivars. According to these two indices the study area falls in the same cluster as Montpellier and Orange in the south of France and Verona in Italy, all located in the Mediterranean climatic zone, as well as the coastal regions of California in the USA, the southern part of Western Australia and the Santiago region in Chile. During the maturation period of Sauvignon blanc (February), day and night temperatures were warm. Mean, minimum and maximum temperatures for February were $21.4^{\circ} \mathrm{C}, 15.6^{\circ} \mathrm{C}$ and $28.3^{\circ} \mathrm{C}$, respectively. However, despite all of the stations being within a radius of $15 \mathrm{~km}$, significant differences in finer climatic aspects could be detected (Table 6).

\section{Summer}

Number of hours (Dec-Feb) with temperatures $>30^{\circ} \mathrm{C}$, growing degree-days (Dec-Feb) and the Huglin index pointed towards Kuils River, Helshoogte and Durbanville being cooler than Papegaaiberg and Devon Valley. Mean and maximum temperature for February differed by $1.8^{\circ} \mathrm{C}$ and $3.1^{\circ} \mathrm{C}$, respectively, between the warmest (Papegaaiberg) and the coolest locality (Durbanville). The February temperature variability index (Gladstones, 1992) showed that the three coolest localities differed in terms of thermal amplitude. (Lower values for this index suggest a more temperate climate, while higher values point towards a more continental climate.) During February the minimum temperature was highest at Kuils River. This could firstly be ascribed to the proximity of the sea and secondly to its location on an east-facing slope, thus warming up earlier in the morning. Proximity to the sea and altitude play a significant role in climatic patterns. The cool moist air of the sea breeze prevents high day temperatures, especially in February (Bonnardot, 1999; Bonnardot et al., 2001). Kuils River and Durbanville, the locations closest to the sea, therefore experienced a maritime climate (lowest temperature variability index due to moderate maximum and minimum temperatures) and, as a result, recorded the fewest hours with temperatures above $30^{\circ} \mathrm{C}$. The cooling effect of the sea breeze decreases rapidly with distance from the sea

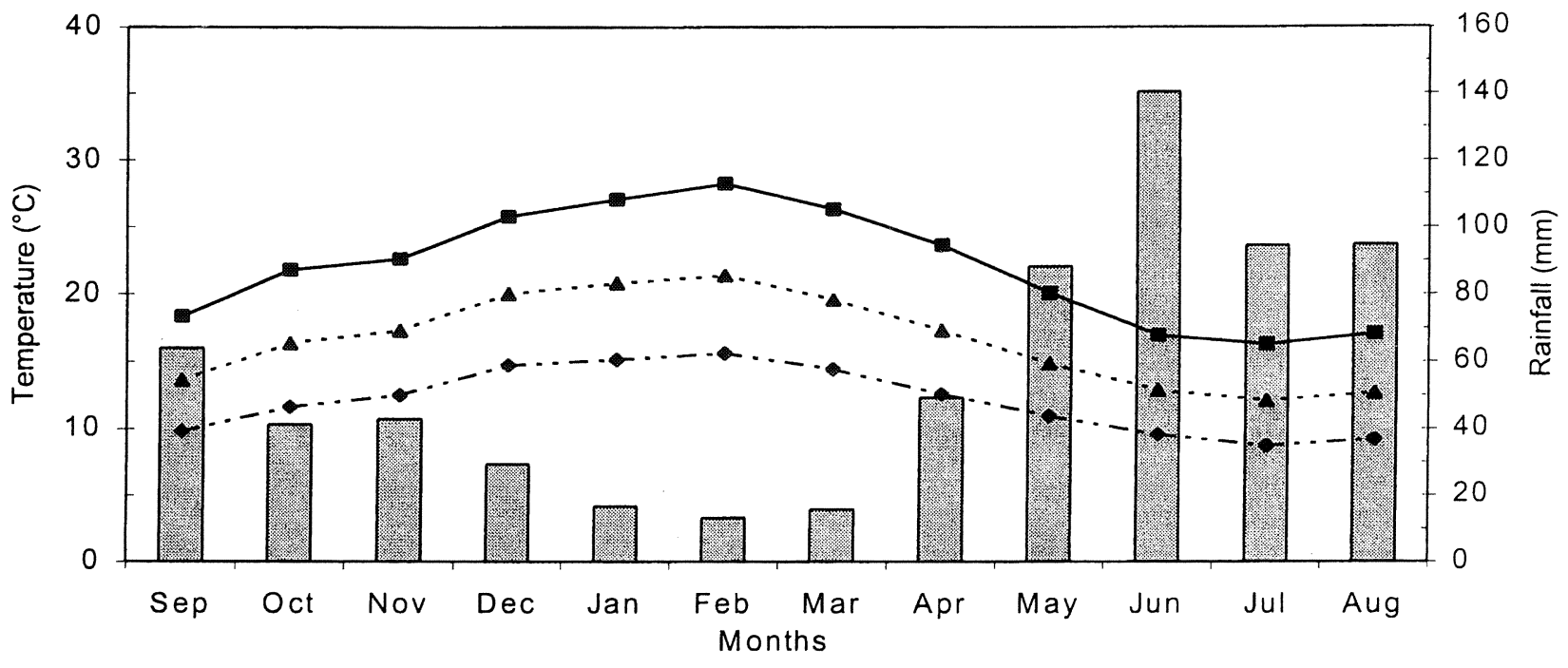

Rainfall $\rightarrow-M a x$. Temp. $\rightarrow-$ Min. Temp. $\cdots \bowtie-M e a n$ Temp.

FIGURE 2

Mean monthly rainfall and temperature (minimum, mean and maximum) values for the five weather stations in the study area (1994-2001). 
TABLE 6

Climatic parameters as measured at five localities in the Stellenbosch /Durbanville districts (mean for the period 03/1994 to 03/2001).

\begin{tabular}{|c|c|c|c|c|c|c|c|c|c|c|c|c|c|}
\hline Locality & $\begin{array}{c}\text { February } \\
\text { mean } \\
\text { temp. } \\
\left({ }^{\circ} \mathrm{C}\right)\end{array}$ & $\begin{array}{l}\text { February } \\
\text { maxi- } \\
\text { mum } \\
\text { temp. } \\
\left({ }^{\circ} \mathrm{C}\right)\end{array}$ & $\begin{array}{c}\text { February } \\
\text { minimum } \\
\text { temp. } \\
\left({ }^{\circ} \mathrm{C}\right)\end{array}$ & $\begin{array}{c}\text { Growing } \\
\text { degree- } \\
\text { days } \\
(\text { Dec-Feb) } \\
\left({ }^{\circ} \mathrm{C}\right)\end{array}$ & $\begin{array}{c}\text { Huglin } \\
\text { index } \\
\left({ }^{\circ} \mathrm{C}\right)\end{array}$ & $\begin{array}{c}\text { Temp. } \\
>30^{\circ} \mathrm{C} \\
\text { (Dec-Feb) } \\
\text { (hours) }\end{array}$ & $\begin{array}{c}\text { Temp. } \\
<12^{\circ} \mathrm{C} \\
\text { (Dec-Feb) } \\
\text { (hours) }\end{array}$ & $\begin{array}{c}\text { February } \\
\text { temp. } \\
\text { varia- } \\
\text { bility } \\
\text { index (1) }\end{array}$ & $\begin{array}{c}\text { Rainfall } \\
\text { (Oct- } \\
\text { Mar) } \\
\text { (mm) }\end{array}$ & $\begin{array}{c}\text { July } \\
\text { mean } \\
\text { temp. } \\
\left({ }^{\circ} \mathrm{C}\right)\end{array}$ & $\begin{array}{l}\text { July } \\
\text { maxi- } \\
\text { mum } \\
\text { temp. } \\
\left({ }^{\circ} \mathrm{C}\right)\end{array}$ & $\begin{array}{l}\text { July } \\
\text { mini- } \\
\text { mum } \\
\text { temp. } \\
\left({ }^{\circ} \mathrm{C}\right)\end{array}$ & $\begin{array}{c}\begin{array}{c}\text { Number } \\
\text { of days } \\
\text { with }\end{array} \\
\text { mean } \\
\text { temp. } \\
<10^{\circ} \mathrm{C} \\
\text { (May- } \\
\text { June) }\end{array}$ \\
\hline Kuils River & $21.1 \mathrm{c}^{(2)}$ & $27.6 \mathrm{c}$ & $16.0 \mathrm{a}$ & 942 b & $2167 b$ & $107 \mathrm{~b}$ & $23 \mathrm{a}$ & $34.5 \mathrm{a}$ & $155 \mathrm{~b}$ & $12.4 \mathrm{ab}$ & $15.8 \mathrm{c}$ & $9.7 \mathrm{a}$ & $3 a$ \\
\hline Papegaaiberg & $22.2 \mathrm{a}$ & $29.8 \mathrm{a}$ & $15.5 \mathrm{c}$ & $1039 \mathrm{~d}$ & $2420 \mathrm{~d}$ & $195 \mathrm{e}$ & $39 \mathrm{~b}$ & $41.4 \mathrm{~b}$ & $153 \mathrm{~b}$ & $12.5 \mathrm{a}$ & $17.3 \mathrm{a}$ & $8.6 \mathrm{~b}$ & $2 \mathrm{a}$ \\
\hline Devon Valley & $21.8 \mathrm{~b}$ & $29.1 \mathrm{~b}$ & $15.8 \mathrm{ab}$ & $1000 \mathrm{c}$ & $2325 \mathrm{c}$ & $164 d$ & $42 \mathrm{~b}$ & $39.0 \mathrm{c}$ & $141 \mathrm{bc}$ & $12.2 \mathrm{bc}$ & $16.6 \mathrm{~b}$ & $8.8 \mathrm{~b}$ & $4 a b$ \\
\hline Helshoogte & $21.3 \mathrm{c}$ & $27.9 \mathrm{c}$ & $15.6 \mathrm{bc}$ & $948 \mathrm{~b}$ & $2146 \mathrm{ab}$ & $125 c$ & $86 \mathrm{c}$ & $37.8 \mathrm{c}$ & $214 \mathrm{a}$ & $11.3 \mathrm{~d}$ & $15.6 \mathrm{c}$ & $7.7 \mathrm{c}$ & $9 \mathrm{c}$ \\
\hline Durbanville & $20.4 \mathrm{~d}$ & $26.7 \mathrm{~d}$ & $15.2 \mathrm{~d}$ & $903 \mathrm{a}$ & $2059 \mathrm{a}$ & $71 \mathrm{a}$ & $37 \mathrm{~b}$ & $35.6 \mathrm{a}$ & $131 \mathrm{c}$ & $11.9 \mathrm{c}$ & $16.0 \mathrm{bc}$ & $8.6 \mathrm{~b}$ & $7 \mathrm{bc}$ \\
\hline
\end{tabular}

(1) Temperature variability index $=\Sigma\left[\left(\mathrm{TD}_{\max }-\mathrm{TD}_{\min }\right)+\left(\mathrm{TM}_{\max }-\mathrm{TM}_{\min }\right)\right]$, where $\mathrm{TD}_{\max }$ and $\mathrm{TD}_{\min }$ are the average daily maximum and minimum and $\mathrm{TM} \mathrm{max}_{\max }$ and $\mathrm{TD}_{\min }$ the average highest maximum and average lowest minimum temperatures for February (Gladstones, 1992).

(2) Values in columns followed by the same letter do not differ significantly $(\mathrm{p} \leq 0.05)$.

(Bonnardot et al., 2001), resulting in the inland stations of Papegaaiberg and Devon Valley experiencing a more continental climate (highest temperature variability index). Higher temperatures at these stations could also have been partly due to the lower altitude and/or aspect (NW and WNW). Helshoogte also experienced a more continental climate, but was cooler than Papegaaiberg and Devon Valley, due to its location at a higher altitude. This locality also experienced the highest rainfall during the active growing season (Oct-Mar) and the highest number of hours with temperatures below $12^{\circ} \mathrm{C}$ (due to cooler nights).

\section{Winter}

Temperature differences between localities were reduced during winter. Mean and maximum temperatures for July differed by $1.2^{\circ} \mathrm{C}$ and $1.7^{\circ} \mathrm{C}$, respectively, between the warmest (Papegaaiberg) and coolest (Helshoogte) locality. The latter locality, situated at the highest altitude and facing south, also experienced the lowest minimum temperatures and the highest number of days with mean temperatures of $<10^{\circ} \mathrm{C}$. Conditions for the release of grapevine buds from dormancy ( 9 consecutive days with mean temperatures below $10^{\circ} \mathrm{C}$ during May and June) should be best at this locality.

The above results showed that, due to the proximity of the sea and the complexity of the topography, finer climatic aspects can vary considerably within the "global" picture for Stellenbosch/ Durbanville. Similar indications were obtained in a study on natural terroir units for viticulture in the Bottelary-SimonsbergHelderberg wine-growing area (Carey, 2001).

\section{Soil water status}

Due to relatively high rainfall up to the end of September (Fig. 2), soils were at field capacity on $1^{\text {st }}$ October. From October to December monthly rainfall averaged $38 \mathrm{~mm}$ for the five localities (Fig. 2), resulting in soil water being partly replenished during the first part of the growing season. Soil water was therefore sufficient to meet the requirements of the grapevines up to the end of December for most soil forms (data not shown). From January to March monthly rainfall averaged only $15 \mathrm{~mm}$ for the five localities, implying that it did not increase soil water content signifi- cantly over this period. Consequently, water deficits were expected for grapevines on some of the soil forms. Theoretically, high degrees of soil-water depletion (Table 7) and water stress were expected for both soils at Kuils River (low clay contents), the Tukulu at Papegaaiberg (warm climate and high gravel content), the Glenrosa at Devon Valley (high gravel content) and the Tukulu at Durbanville (low rainfall during summer). Lowest water stress was expected for grapevines on both soils at Helshoogte. Leafwater potentials (measured around noon) for January and February (Table 7) showed the highest water stress for Kuils River (both soils) and the Glenrosa at Devon Valley in comparison to lower stress at Helshoogte. At Papegaaiberg (warmest location), however, water stress appeared to be low for the Tukulu, as well as the Avalon. Excessive water stress could induce stomata closure during the warmest part of the day (Smart \& Coombe, 1983 and

\section{TABLE 7}

Plant available soil-water content (0-1.2 m) at end of March $\left(\mathrm{PAW}_{\mathrm{e}}\right)$ and mean leaf-water potential (January and February) at five localities in Stellenbosch/Durbanville districts (1994 - 2001).

\begin{tabular}{llcc}
\hline Locality & Soil form & $\begin{array}{c}\text { PAW } \\
(\mathbf{m m})\end{array}$ & $\begin{array}{c}\text { Leaf-water potential } \\
(-\mathbf{M P a})\end{array}$ \\
\hline Kuils River & Tukulu & 13 & 1.53 \\
& Vilafontes & 15 & 1.56 \\
Papegaaiberg & Avalon & 31 & 1.34 \\
& Tukulu & -6 & 1.35 \\
& & & 1.50 \\
Devon Valley & Oakleaf & 34 & 1.59 \\
& Glenrosa & -21 & 1.38 \\
Helshoogte & Tukulu & 57 & 1.43 \\
& Hutton & 38 & 1.27 \\
& & & 1.28 \\
\hline
\end{tabular}


references therein). At Papegaaiberg this may have resulted in leaf-water potentials not giving a true reflection of water stress. The fact that potentials at Papegaaiberg remained relatively constant over January and February, while all the other localities showed lower values (higher water stress) in February than in January (data not shown), supported this assumption. Under conditions of excessive water stress, stem- or pre-dawn leaf-water potentials should rather be measured (Choné et al., 2001). At Durbanville grapevines experienced the lowest water stress, mainly on account of the cool climate (Table 6). Apart from the differences between localities, leaf-water potentials also differed between grapevines on different soil forms at the same locality. In comparison to their respective counterparts, higher water stress was measured for the Vilafontes at Kuils River, the Glenrosa at Devon Valley and the Hutton at Helshoogte.

Vegetative growth (cane mass/m cordon) tended to increase with an

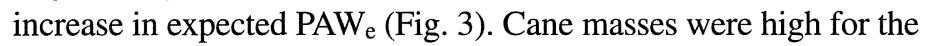
Tukulu at Kuils River and the Hutton at Helshoogte in comparison

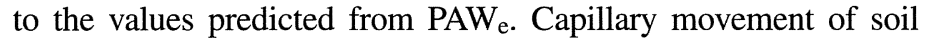
water from the deeper layers could have resulted in $\mathrm{PAW}_{\mathrm{e}}$ (calculated to $1.2 \mathrm{~m}$ ) being under-estimated for these soils. For the
Oakleaf at Devon Valley and the Avalon at Papegaaiberg cane masses were low in comparison to predicted values. In view of Devon Valley and Papegaaiberg being the warmest localities (Table 6), excessively high temperatures may have suppressed $\mathrm{CO}_{2}$ assimilation, responsible for vegetative growth (Williams et al., 1994 and references therein). In comparison to their respective counterparts, however, cane masses were still relatively high for the Oakleaf at Devon Valley and the Avalon at Papegaaiberg, thus illustrating the effect of soil form on vegetative growth, even at warm localities.

\section{Grapevine performance}

\section{Phenology}

Budburst (Table 8) was earliest at Kuils River (both soils), Devon Valley (both soils) and Durbanville (Tukulu only), while it was significantly later for Papegaaiberg (both soils), Helshoogte (both soils) and Durbanville (Westleigh only). In view of Papegaaiberg being the warmest locality, in contrast to Durbanville being the coolest (Table 6), date of budbreak did not appear to be wholly temperature dependent. Soil temperatures during early spring may have affected the onset of budburst (Alleweldt \& Hofäcker, 1975). Evidence for this assumption was found at Durbanville,

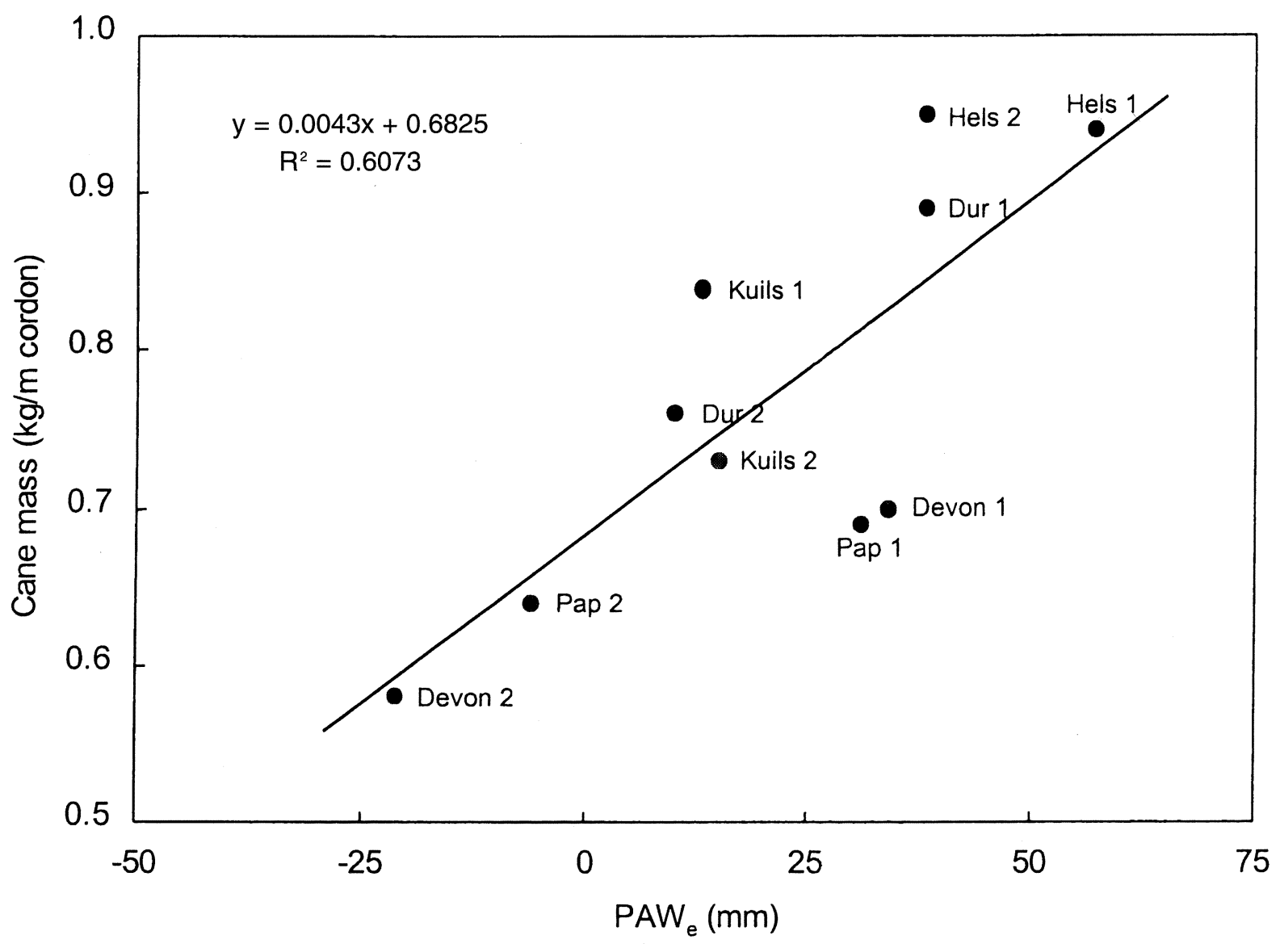

FIGURE 3

Plant available soil-water content (0-1.2 m) at the end of March $\left(\mathrm{PAW}_{\mathrm{e}}\right)$ and cane mass for the five localities in Stellenbosch/Durbanville districts (1994-2001). (Kuils = Kuils River, Pap = Papegaaiberg, Devon = Devon Valley, Hels = Helshoogte, Dur = Durbanville). 
TABLE 8

Effect of locality and soil form on phenology and plant performance for Sauvignon blanc/99 Richter (mean from 1994 to 2001).

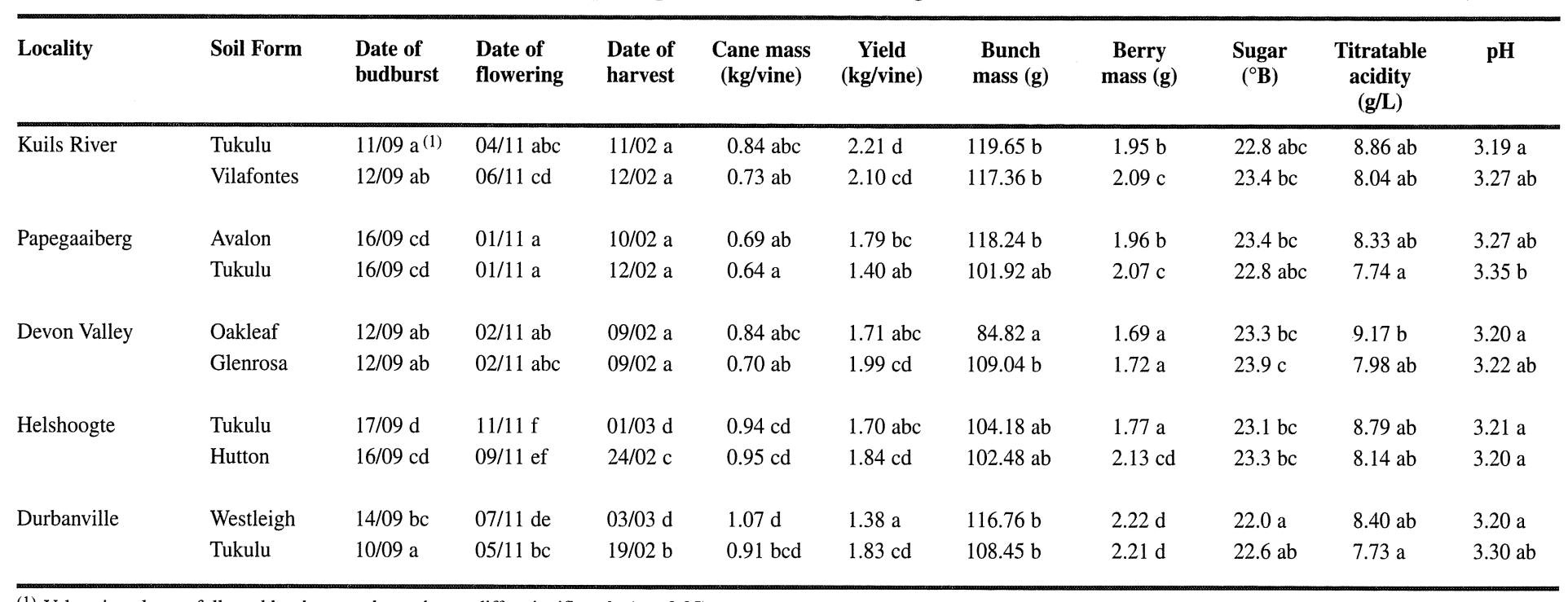

(1) Values in columns followed by the same letter do not differ significantly $(\mathrm{p} \leq 0.05)$.

\section{TABLE 9}

Number of days and number of heat units experienced from budburst to harvest at five localities in Stellenbosch/Durbanville districts (mean from 1994 to 2001).

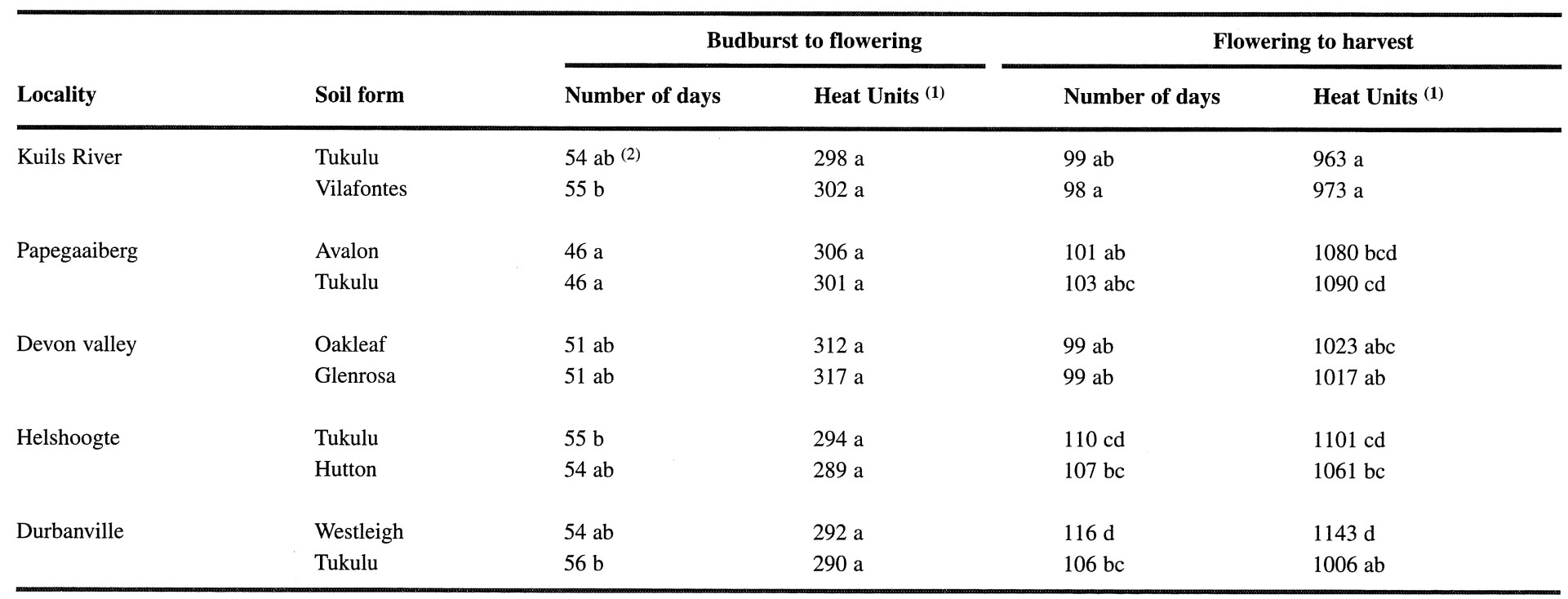

(1) Growing degree-days above $10^{\circ} \mathrm{C}$ (Amerine \& Winkler, 1944).

(2) Values in columns followed by the same letter do not differ significantly $(\mathrm{p} \leq 0.05)$.

where budburst occurred four days later for the Westleigh (high water table during winter and therefore lower soil temperatures) than for the Tukulu (drier and warmer than the Westleigh). Time of flowering, however, did not differ within a specific locality and was earliest for the two warmest localities (Papegaaiberg and Devon Valley), while it was latest for one of the cooler localities (Helshoogte). Intermediate flowering dates were found for the other cool localities (Kuils River and Durbanville). Even though the number of days between budburst and flowering differed between localities, all localities experienced a comparable number of heat units (ranging from 289 to 317) over this period (Table 9). These results were in agreement with the suggestion (Huglin \& Schneider, 1998) that date of flowering is largely dependent on temperature, especially on maximum temperatures.

Grapes from the two warmer localities (Papegaaiberg and Devon Valley) were harvested one week to three weeks earlier than those from two of the cooler localities (Helshoogte and Durbanville). For these four localities the number of heat units 
experienced between flowering and harvest ranged from 1006 to 1143 (Table 9). In the case of the other relatively cool locality (Kuils River) grapes ripened at the same time as those from the warmer localities (Table 8). This was probably on account of the low water-holding capacities of soils at Kuils River (Table 2), resulting in relatively high water stress during the latter parts of the season (Table 7). In spite of relatively cool conditions, ripening was thus enhanced, resulting in a low number of heat units (mean value of 968) between flowering and harvest (Table 9). At Durbanville grapes from the wetter soil (Westleigh) were harvested 12 days later than those from the drier soil (Tukulu). Grapevines on the Westleigh grew vigorously (Table 8) and active growth could still be detected during the ripening phase, resulting in sugar accumulation being slowed down. Different soil water regimes could also have been the reason why grapes from the wetter soil (Tukulu) at Helshoogte were harvested 5 days later than those from the drier one (Hutton). Date of ripening was, therefore, not affected by climate only, but also by the soil.

\section{Growth and yield}

In general, the highest cane masses (Fig. 3, Table 8) were obtained at the localities (Helshoogte and Durbanville), where soils contained relatively high amounts of organic C (Table 4), usually in combination with a high soil water status (Table 7). Yield was lowest for the Westleigh at Durbanville, probably on account of infertility, induced during spring by too vigorous growth at floral initiation and therefore lower sunlight interception in the vine canopy. In contrast, yield was also low for the Tukulu at the warmest locality (Papegaaiberg). In this case low yield could be ascribed to a low number of bunches per vine and fewer berries per bunch (Table 8). At this locality a combination of factors (high temperature/soil with a high gravel fraction and a low water-holding capacity/poor root distribution) resulted in a terroir with low potential for Sauvignon blanc. Yield was highest at the relatively cool locality (Kuils River), where grapes ripened earliest. Comparable yields $(1.70-2.09$ $\mathrm{kg} / \mathrm{vine}$ ) were obtained at the other sites. Berries were largest at the coolest locality (Durbanville) and smallest at one of the warmer localities (Devon Valley). At three of the localities (Kuils River, Papegaaiberg and Helshoogte) berry size was also significantly affected by soil form.

\section{Must composition}

In spite of grapes from the Westleigh at Durbanville being harvested last, sugar content was still the lowest (Table 8). In contrast, a significantly higher sugar content was obtained for grapes from the Tukulu at Helshoogte, which were also harvested relatively late. Slow ripening in the case of the Westleigh at Durbanville could obviously be ascribed to problematic soil conditions resulting in excessive vegetative growth and not to climatic factors. In general, grapes from all other sites could be harvested fairly close to the desired sugar content $\left(23^{\circ} \mathrm{B}\right)$.

Titratable acidity was lowest and $\mathrm{pH}$ highest for grapes from the Tukulu at Papegaaiberg (Table 8). This may have been on account of the warm climate (Table 6), leading to metabolism of malic acid, and the high $\mathrm{K}$ content of the soil (Table 5). However, low titratable acidity and a moderately high $\mathrm{pH}$ value was also found for the Tukulu at Durbanville, despite the cool climate and low soil K. The lower acidity can possibly be ascribed to canopy-management practices followed at this locality, which resulted in a large per- centage of bunches being exposed (determined by means of point quadrat method - data not shown). The reverse (high acidity, relatively low $\mathrm{pH}$ ) was true for the Oakleaf at Devon Valley, despite high maximum temperatures (Table 6) and high soil K. At the same locality, however, acidity tended to be lower and $\mathrm{pH}$ higher for the Glenrosa (higher water stress). Any factor, such as water stress, that reduces the photosynthetic activity of leaves will result in increased potassium accumulation in berries and higher must $\mathrm{pH}$ values (Freeman et al., 1982). It must be noted that the trial was carried out in commercial vineyards with different clones, which may have had an effect on sugar/ acid/pH balances. Within a specific locality, however, acidity tended to be lowest and/or $\mathrm{pH}$ highest for the soil with the lowest water content. Apart from the effect of contrasting associations of landscape/aspect/climate on the performance of Sauvignon blanc (phenology, vigour, yield, sugar accumulation, acidity), soil type may therefore also have a pronounced effect. Wine style should differ between different localities and, in some cases, also between soils at the same locality.

\section{CONCLUSIONS}

It is often difficult to relate soils to specific geological parent materials. Management practices (especially loosening and chemical amelioration of soils before grapevines are planted) may change the chemical properties of soils to such an extent that inherited characteristics are no longer distinguishable. Potassium levels nevertheless appear to be lower for soils originating from phyllitic shales in comparison to granitic soils. Geology also plays a role in that it influences the physical properties (especially particle size distribution and water-holding capacity) of soils. Geological maps may therefore be valuable tools where decisions concerning cultivars and rootstocks must be made for specific localities. Such maps must, however, be considerably more detailed than those which are currently available.

Within the Western Cape of South Africa appreciable climatic differences can occur between localities in close proximity. This is largely on account of different aspects, altitudes and distances from the sea. These subtle climatic differences do have an effect on phenology and on the chemical composition of Sauvignon blanc grapes. Ripening can either be enhanced or delayed, while sugar/acid/pH balances are also affected. These differences should be reflected in wine quality.

Even though climate appears to be the most important driving force affecting grapevine performance, the effect of soil cannot be discounted. Especially in the case of soils with low water-holding capacities the advantages of a "good" climate cannot always be fully exploited. High water stress may result in grapes with low acidity/high $\mathrm{pH}$. On the other hand, adequate ripening may also be problematic on soils that are too wet. Even though the use of different clones created limitations in the current study, it may still be argued that the correct scion/rootstock combination will help to ensure that each situation is exploited to its fullest advantage.

In the past it has been argued that application of the terroir concept is of doubtful value in relatively warm wine-growing countries such as South Africa. Results from this study, however, suggested that Sauvignon blanc wines with region-specific characteristics can be produced within specific districts. Differences in wine style, as induced by different terroirs, should be the subject of further research. 


\section{LITERATURE CITED}

Alleweldt, G. \& Hofäcker, W., 1975. Einfluss von umweltfaktoren auf austrieb, blüte, fruchtbarkeit und triebwachstum bei der rebe. Vitis 14, 103-115.

Amerine, M.A. \& Winkler, A.J., 1944. Composition and quality of musts and wines of Californian grapes. Hilgardia 15, 493-673.

Böhm, W., 1979. Methods of studying root systems. Ecological studies, Vol. 33. Springer-Verlag, Berlin.

Bonnardot, V., 1999. Étude préliminaire des brises de mer pendant la période de maturation dans la région viticole de Stellenbosch-Klein Drakenstein en Afrique du Sud. AIC Publication 12, 26-33

Bonnardot, V., Carey, V., Planchon, O. \& Cautenet, S., 2001. Sea breeze mechanism and observations of its effects in the Stellenbosch wine producing area. Wynboer $147,10-14$

Carey, V., 2001. Spatial characterization of natural terroir units for viticulture in the Bottelaryberg-Simonsberg-Helderberg winegrowing area. M.Sc. Thesis, Stellenbosch University, Private Bag X1, 7602 Matieland (Stellenbosch), South Africa.

Carey, V.A., Bonnardot, V.M.F., Schmidt, A. \& Theron, J.C.D., 2001. The interaction between vintage, vineyard site (mesoclimate) and wine aroma of Vitis vinifera L. cvs. Sauvignon blanc, Chardonnay and Cabernet Sauvignon in the Stellenbosch-Klein Drakenstein wine growing area, South Africa (1996-2000). In: Proc. $26^{\text {th }}$ O.I.V. World Vine \& Wine Congress, October 2001, Adelaide, Australia. pp. 139-152

Choné, X., Van Leeuwen, C., Dubourdieu, D. \& Gaudillère, J.P., 2001. Stem water potential is a sensitive indicator of grapevine water status. Ann. Bot. 87, 477-483.

Conradie, W.J., 1983. Liming and choice of rootstocks as cultural techniques for vines in acid soils. S. Afr. J. Enol. Vitic. 4, 39-44.

Conradie, W.J., 1986. Utilisation of nitrogen by the grapevine as affected by time of application and soil type. S. Afr. J. Enol. Vitic. 7, 76-82.

Conradie, W.J. \& Saayman, D., 1989. Effects of long-term nitrogen, phosphorus and potassium fertilization on Chenin blanc vines. II. Leaf analyses and grape composition. Am. J. Enol. Vitic. 40, 91-98.

Coombe, B.G., 1995. Adoption of a system for identifying grapevine growth stages. Austr. J. Grape Wine Res. 1, 104-110.

De Villiers, F.S., Schmidt, A., Theron, J.C.D. \& Taljaard, R., 1996. Onderverdeling van die Wes-Kaapse wynbougebiede volgens bestaande klimaatskriteria. Wynboer Tegnies 78, 10-12.

Etourneaud, F. \& Loué, A., 1984. Le diagnostic pétiolaire de la vigne en relation avec l'interprétation de l'analyse de sol pour le potassium et le magnésium. In: Proc. $6^{\text {th }}$ International Colloquium for the optimisation of plant nutrition, September 1984, Montpellier, France. pp. 189-198.

Freeman, B.M., Kliewer, W.M. \& Stern, P., 1982. Influence of wind breaks and climatic region on diurnal fluctuation of leaf water potential, stomatal conductance, and leaf temperature of grapevines. Am. J. Enol. Vitic. 33, 233-236.

Gladstones, J., 1992. Viticulture and Environment. Winetitles, Adelaide.

Huglin, P., 1978. Nouveau mode d'évaluation des possibilités héliothermiques d'un milieu viticole. CR Acad. Agric., 1117-1126.

Huglin, P. \& Schneider, C., 1998. Biologie et Écologie de la vigne ( $2^{\text {nd }}$ ed). Lavoisier, Paris.

Kendrew, W.G., 1961. The climates of the Continents. Oxford University Press, London.

Le Roux, E.G., 1974. 'n Klimaatsindeling van die Suidwes-Kaaplandse Wingerdbougebiede. M.Sc. Thesis, Stellenbosch University, Private Bag X1, 7602 Matieland (Stellenbosch), South Africa.

Marais, J., Hunter, J.J. \& Haasbroek, P.D., 1999. Effect of canopy microclimate, season and region on Sauvignon blanc grape composition and wine quality. S. Afr. J. Enol. Vitic. 20, 19-30.
Morlat, R., 1996. Eléments importants d'une méthodologie de caractérisation des facteurs naturels du terroir, en relation avec la réponse de la vigne à travers le vin. In : Proc. $1^{\text {er }}$ Colloque International "les Terroirs Viticoles", 17-18 July 1996 Angers, France. pp. 17-31.

Myburgh, P.A., 1998. Water consumption of South African vineyards: A modelling approach based on the quantified combined effects of selected viticultural, soil and meteorological parameters. PhD Dissertation, Stellenbosch University, Private Bag X1, 7602 Matieland (Stellenbosch), South Africa.

Rankine, B.C., Fornachon, J.C.M., Boehm, E.W. \& Cellier, K.M., 1971. Influence of grape variety, climate and soil on grape composition and on the composition and quality of table wines. Vitis $10,33-50$.

Saayman, D., 1977. The effect of soil and climate on wine quality. In: Proc. Int Symp. Quality of the Vintage, 14-21 February 1977, Cape Town, South Africa. pp. 197-208.

Saayman, D., 1981. Wingerdvoeding. In: Burger, J. \& Deist, J. (eds). Wingerdbou in Suid-Afrika.

Nietvoorbij, Stellenbosch, South Africa. pp. 343-383.

Saayman, D., 1992. Natural influences and wine quality. Part 2: The role of soil. Wynboer, August 1992, 49-51.

Saayman, D., 1998. The development of vineyard zonation and demarcation in South Africa. In: Proc. Simposio Internazionale Territorio \& Vino, 19-24 May 1998, Siena, Italy. pp. 35-42.

SAWIS, 2000. South African Wine Industry Statistics No. 24, SAWIS, Paarl, South Africa.

Scholander, P.F., Hammel, H.T., Bradstreet, E.D. \& Hemmingsen, E.A., 1965. Sap pressure in vascular plants. Science 148, 339-346.

Schulze, B.R., 1972. South Africa, World Survey of Climatology. Elsevier Publishing Company, 10 (15), 501-586.

Seguin, G., 1983. Influence des terroirs viticoles sur la constitution et la qualité des vendanges. Bull. OIV 56 (627), 8-12.

Seguin, G., 1986. "Terroirs" and pedology of wine growing. Experientia 42, 861873.

Smart, R.E. \& Coombe, B.G., 1983. Water relations of grapevines. In: Kozlowsk T.T. (ed). Water deficits and plant growth VII. Academic Press, New York. pp. 137-196.

Smart, R.E. \& Dry, P.R., 1980. A climatic classification for Australian viticultural regions. Austr. Grapegrower and Winemaker 196, 8-16.

Soil Classification Working Group, 1991. Soil classification - A taxonomic system for South Africa. Department of Agricultural Development: Memoirs on natural agricultural resources of South Africa No. 15, Department of Agricultural Development, Pretoria, South Africa.

Stevenson, F.J., 1986. Cycles of soil - Carbon, Nitrogen, Phosphorus, Sulfur, Micronutrients. John Wiley \& Sons, New York, USA.

Theron, J.N., Gresse, P.G., Siegfried, H.P. \& Rogers, J., 1992. The Geology of the Cape Town Area. Explanation of Sheet 3318. Department of Mineral and Energy Affairs, Pretoria, South Africa.

Tonietto, J., 1999. Les macroclimats viticoles mondiaux et l'influence du mésoclimat sur la typicité de la Syrah et du Muscat de Hambourg dans le Sud de la France - Méthodologie de caractérisation. ENSA-Montpellier. Doctoral thesis.

Van Schoor, L.H., 2001. Geology, particle size distribution and clay fraction mineralogy of selected vineyard soils in South Africa and the possible relationship with grapevine performance. M.Sc. Thesis, Stellenbosch University, Private Bag X1, 7602 Matieland (Stellenbosch), South Africa.

Van Zyl, P., 2000. Stellenbosch Offspring. In: Stellenbosch Appellations and Flagships. Supplement to Wine, June 2000.

Visser, J.N.J., 1964. Analyses of rocks, minerals and ores. Handbook 5. Geological Society of South Africa, Pretoria, South Africa 
White, R.E., 1987. Introduction to the principles and practice of soil science. $2^{\text {nd }}$ Edition, Blackwell Scientific Publications, Oxford, UK.

Williams, L.E., Dokoozlian, N.K. \& Wample, R., 1994. In: Schaffer, B. \& Anderson, P.C. (eds). Handbook for environmental physiology of fruit crops, Vol I, Temperate crops. CRC Press, Boca Raton. pp. 85-133.

Wilson, J.E., 1998. Terroir. The role of geology, climate and culture in the making of French Wines. University of California Press, Berkeley, California.
Winkler, A.J., Cook, J.A., Kliewer, W.M. \& Lider, L.A., 1974. General Viticulture. University of California Press, Berkeley, California.

Wooldridge, J., 1988. The potassium supplying power of certain virgin upland soils of the Western Cape. M.Sc. Thesis, Stellenbosch University, Private Bag X1, 7602 Matieland (Stellenbosch), South Africa. 